\title{
DIVERSOS MATICES DE LA REGULACIÓN DE LA CLÁUSULA PENAL EN EL ORDENAMIENTO ESPAÑOL Y ALEMÁN *
}

\author{
Cristina Fuenteseca Degeneffe \\ Profesora Titular de Derecho Civil. UCM \\ cfuentes@psi.ucm.es
}

\begin{abstract}
RESUMEN
Se analizan uno a uno los parágrafos que el BGB dedica a la cláusula penal, así como las distintas opiniones doctrinales vertidas en Alemania con el fin de hallar los puntos comunes o divergentes con la normativa española acerca de este extremo (Código Civil, Compilación navarra, Propuesta de Modernización del Código Civil en materia de Obligaciones y Contratos). Todo ello con el objetivo de arrojar luz sobre una futura unificación del Derecho de obligaciones europeo.

Palabras clave: cláusula penal, derecho comparado español-alemán.
\end{abstract}

\section{ABSTRACT}

The paragraphs the $B G B$ dedicated to the penal clause are examined one by one, as well as the different doctrinal views expressed in Germany in order to find the common or divergent points in relation to Spanish regulations on this question (Civil Code, Navarre Compilation, Proposed Modernization of the Civil Code in terms of Obligations and Contracts). All with the aim of shedding light on a future unification of the European law of obligations.

Keywords: penal clause, Spanish-German comparative law.

\section{ZUSAMMENFASSUNG}

Es werden alle einzelnen Paragraphen des BGB untersucht, die die Strafklausel betreffen sowie die in Deutschland hierzu geäußerte Rechtslebre, um diesbezügliche gemeinsame und abweichende Punkte zum spanischen Recht zu finden (Spanisches Bürgerliches Gesetzbuch, Gesetzessammlung Navarra, Vorschlag zur Modernisierung des Spanischen BGB in Bezug auf Pflichten und Verträge). Das Ziel der gesamten Untersuchung ist es, zu beleuchten, wie eine zukünftige Vereinheitlichung des europäischen Rechts in Bezug auf das Schuldrecht erzielt werden kann.

Schlüsselwörter: Strafklausel, vergleichendes Recht spanisch-deutsch.

* Este trabajo se enmarca en el Proyecto de Investigación concedido por el Ministerio de Ciencia e Innovación. Referencia: DER2010-18817 (subprograma JURI). Título: «Principios de Derecho Europeo. Marco Común de Referencia. Compraventa: una adaptación imprescindible», 2011.

Este trabajo se enmarca en el Grupo de Investigación Complutense 931499-933, «Sujetos protegidos y contratación», 2009. 
Cristina Fuenteseca Degeneffe Diversos matices de la regulación de la cláusula penal...

SUMARIO: I. EL PUNTO DE PARTIDA.-II. EL EXAMEN DE LAS DIVERSAS RÚBRICAS DE LOS PARÁGRAFOS 339 A 345 BGB.-III. REQUISITOS DE EFECTIVIDAD DE LA PENA.-IV. LA CLÁUSULA PENAL EN CASO DE INCUMPLIMIENTO TOTAL.-1. Su regulación en el BGB y en el Código Civil español. 2.-El papel del acreedor en la elección y la protección del deudor.-3. La prestación parcial.-4. La reparación del daño en lugar de la prestación.-V. LA PENA CONTRACTUAL EN CASO DE CUMPLIMIENTO NO ADECUADO.-VI. LA PENA QUE NO CONSISTE EN UNA PRESTACIÓN PECUNIARIA.- - 1. La pena consistente en la pérdida de derechos.-2. La reparación de daños cuando la pena no consiste en dinero.-3. La rebaja de la pena que no consiste en dinero.-VII. LA REBAJA DE LA PENA.-VIII. LA INEFICACIA DE LA PROMESA DE PENA.-IX. LA CARGA DE LA PRUEBA.

\section{EL PUNTO DE PARTIDA}

Un examen de Derecho comparado de un punto concreto entre dos ordenamientos europeos como el español y el alemán se simplifica en gran medida cuando puede tomarse como punto de partida un aspecto común que subyace en ambos.

En este sentido, los antecedentes históricos en los dos casos encuentran claro apoyo en el Derecho romano y, por ello, cabría considerar como hilo conductor una base común aglutinadora de puntos que podrían considerarse muy semejantes ${ }^{1}$. De ellos me ocupo precisamente en el presente trabajo.

Actualmente este extremo cobra asimismo importancia extraordinaria considerando las modernas tendencias unificadoras en materia de Derecho privado, especialmente del Derecho de obligaciones ${ }^{2}$. La detección de líneas semejantes que comparten un pasado común contribuirá, en gran medida, para lograr el objetivo de la unificación del Derecho privado europeo facilitando esta tarea que no resulta nada sencilla.

Además es preciso destacar que el Schuldrechtsmodernisierungsgesetz (2002) no ha tocado, en sus aspectos más esenciales, los parágrafos que el BGB dedica a la cláusula penal. Luego no es una cuestión que haya sido objeto de recientes modificaciones. Y éste es otro punto importante al efectuar un análisis de Derecho comparado, pues las opiniones doctrinales vertidas en Alemania acerca de estos parágrafos no son recientes como requie-

${ }^{1}$ En el Derecho alemán no hay gran ruptura con la tradición de Derecho común, H. G. Hermann, «Vertragsstrafe», en R. Zimmermann (ed.), Schuldrecht. Allgemeiner Teil, $\S \S 241-432$, vol. II, Tübingen, 2007, p. 2051.

2 Por ejemplo, el marco común de referencia, DRAFT, cuyo contenido acerca de este aspecto destaco en el presente trabajo. 
ren las disposiciones modificadas en el año 2002, sino que son tradicionales y pueden ser anteriores a esa fecha. En el Derecho español tampoco han sufrido modificación alguna los preceptos dedicados a la cláusula penal.

Se trata, por tanto, de un tema clásico, pero muy vigente en su aplicación práctica, pues modernamente aparece ligado a las condiciones generales de la contratación, y ello tanto en España como en Alemania ${ }^{3}$. En consecuencia, cobra asimismo relevancia en el ámbito del derecho del consumidor.

En el presente trabajo sólo me ocuparé de lo que la doctrina alemana mayoritaria considera cláusula penal. En este sentido dejan fuera de tal concepto lo que denominan Schadenspauschalen, Schadensersatzpauschale y Schadenspauschalierungsabreden, distinguiendo esta última figura de la cláusula penal ${ }^{4}$.

\section{EL EXAMEN DE LAS DIVERSAS RÚBRICAS DE LOS PARÁGRAFOS 339 A 345 BGB}

El comienzo de este análisis de Derecho comparado tiene que partir de una primera aproximación a los parágrafos del BGB, y lo primero que encontramos, antes del contenido mismo de cada uno de ellos, son las diversas rúbricas que presiden éstos. Por eso dedico unas breves líneas a resaltar lo que de ellas me parece más llamativo.

Basta con una simple lectura de los parágrafos 339 al 345 BGB frente a los arts. 1.152-1.155 de nuestro Código Civil para detectar una división clara en apartados y materias en el Código Civil alemán que es mucho menos precisa en el nuestro.

Es suficiente con un examen de las diferentes rúbricas que encabezan cada uno de los mencionados parágrafos del BGB. Con ellas se delimita claramente la cuestión objeto de regulación. Esto, sin embargo, no existe respecto de cada precepto de nuestro Código Civil. Tales rúbricas brindan

3 Véase el parágrafo 309.6 BGB donde se declara la ineficacia en las condiciones generales de la contratación de la cláusula penal.

${ }^{4}$ P. GotTWALD, «Paragraph 339», en Münchener Kommentar zum Bürgerlichen Gesetzbuch, vol. II, Schuldrecht. Allgemeiner Teil, 4. ${ }^{\text {a }}$ ed., München, 2003, p. 2172; W. FIKENTSCHER y A. Heinemann, Schuldrecht, Berlin, 2006, p. 87; H. Brox y W.-D. Walker, Allgemeines Schuldrecht, München, 2007, p. 102; H. G. Hermann, op. cit., p. 2063; D. Medicus, «Vorbemerkungen vor 339 bis 345 (Vertragsstrafe)», en H. Prütting, G. Wegen y G. Weinreich, BGB Kommentar, Luchterhand, 2009, p. 608. Únicamente S. SCHAUB, «Vorbemerkung 339345», en H. P. Westermann (ed.), Erman Bürgerliches Gesetzbuch, I, Köln, 2008, p. 1557, señala la dificultad de distinguir cláusula penal y Schadenspauschalierungsabreden. 
orden y claridad contribuyendo a la sistematización de los diversos extremos. Antes de estudiar cada uno de los singulares parágrafos se expone de antemano el punto a tratar.

De este modo, y con carácter previo al estudio más detallado de su contenido, me detendré en las rúbricas de los parágrafos mencionados anteriormente. Así, el 339 lleva por rúbrica «Eficacia de la pena contractual»; el 340, «La promesa de pena en caso de incumplimiento»; el 341, «La promesa de pena para el cumplimiento inadecuado»; el 342, «La pena distinta de la pecuniaria»; el 343, «Rebaja de la pena»; el 344, «Promesa de pena ineficaz», y el 345, «Carga de la prueba».

En consecuencia, ya para comenzar, encontramos aquí aspectos que nuestro Código Civil no regula expresamente. Así, la tan nítida distinción entre los parágrafos 340 y 341 BGB al diferenciar el incumplimiento total de los casos en que hubo algún cumplimiento aunque no se correspondiese exactamente con lo pactado. Incluso el contenido del parágrafo 339 aclara cuestiones que no se encuentran en nuestro Código Civil, como determinar exactamente el momento de la eficacia de la pena, incluso en las obligaciones de no hacer ${ }^{5}$.

También el parágrafo 342 BGB contempla expresamente la pena que no consiste en dinero, frente a nuestro Código Civil que no se pronuncia acerca de este extremo en particular. Asimismo, el parágrafo 345 BGB regula otra cuestión que no encontramos en los arts. 1.152-1.155 de nuestro Código Civil como la carga de la prueba.

Concluyendo, es suficiente un examen superficial de las rúbricas de los parágrafos del BGB relativos a la pena contractual para apreciar su regulación ordenada racionalmente en diversos puntos que contribuyen a esclarecer la figura en cuestión, frente al más escaso contenido de nuestro Código Civil.

A todo ello hay que añadir el preponderante papel que en esta problemática de la cláusula penal juega la autonomía de la voluntad. La mayoría de los parágrafos del BGB acerca de este extremo son dispositivos. En nuestro Código Civil se impone el art. 1.255 sobre los escasos preceptos relativos a la cláusula penal, exceptuando lo establecido en la normativa relativa al consumidor. Aquí me ocuparé del tenor literal de los mencionados Códigos y también de las diversas opiniones doctrinales vertidas acer-

5 Para las obligaciones de no hacer, vid. F. SÁnchez Román, Estudios de Derecho civil, t. IV, Madrid, 1899, p. 104: «Otra cosa es el caso de las obligaciones consistentes en no hacer, en las que la accesoria penal será exigible desde el momento en que se realice el hecho prohibido, cualesquiera que fueren sus consecuencias». 
Cristina Fuenteseca Degeneffe Diversos matices de la regulación de la cláusula penal...

ca del mismo. Pero no incidiré en los múltiples acuerdos que los contratantes puedan introducir en cada particular contrato.

\section{REQUISITOS DE EFECTIVIDAD DE LA PENA}

Comienzo con este apartado dedicado a la eficacia de la pena contractual con el fin de seguir el orden marcado por los parágrafos del BGB. No obstante, entiendo que el parágrafo 339 BGB no es el más relevante en la regulación de la cláusula penal. Posiblemente el contenido más importante se refleja en los parágrafos 340 hasta el 343 BGB, de los que me ocupo posteriormente siguiendo su ubicación sistemática, planteándose en ellos cuestiones de mayor trascendencia jurídica.

Este parágrafo 339 tiene carácter introductorio y opera a modo de presupuesto de los que le siguen. Su contenido, igual que el art. 1.152.2 de nuestro Código Civil, se encuentra vinculado con otros aspectos del Derecho de obligaciones como la mora, la culpa del deudor, la imposibilidad... Se trata de determinar en qué momento adquiere su eficacia la obligación penal, la cuestión radica en concretar el instante en que comienzan los efectos de aquélla ${ }^{6}$. Este extremo tiene caracteres generales susceptibles de aparecer respecto de otras obligaciones distintas de la penal. Es decir, la idea de la eficacia o la exigibilidad de una obligación no se da únicamente en materia de cláusula penal. Por este motivo, tanto en el BGB como en el Código Civil español existen otros preceptos cuya regulación gira más concretamente en torno al tema de la cláusula penal ahondando en mayor medida en las diversas cuestiones problemáticas susceptibles de aparecer. Y a estas últimas dedicaré una atención más extensa en los siguientes apartados.

El parágrafo 339 BGB contempla, según indica la rúbrica que lo preside, la «Eficacia de la pena contractual» (Verwirkung der Vertragsstrafe): «Si el deudor promete al acreedor el pago de una suma de dinero como pena para el caso de que no cumpla su obligación o no la cumpla de modo adecuado, será eficaz la pena cuando se retrase (wenn er in Verzug kommt). Si la prestación debida consiste en un no hacer, la eficacia se producirá cuando se realice la prestación contraria».

${ }^{6}$ L. Díez-Picazo y A. Gullón, Sistema de Derecho civil, vol. II, 9. ${ }^{a}$ ed., Madrid, 2004, p. 159, operan con la noción de vencimiento de la cláusula penal: «Pero nada impide que se origine en otro negocio separado, y que se pacte también con posterioridad al negocio creador de la obligación, siempre que sea anterior al momento de su vencimiento». 
La eficacia de la pena consiste, por tanto, en la entrada en vigor de las circunstancias que permiten al acreedor exigir la pena. Este parágrafo puede dividirse en dos partes. En la primera se refiere a obligaciones de hacer y en la segunda a las obligaciones de no hacer. Ya en este parágrafo 339 se indican las cuestiones que serán objeto de tratamiento separado en los siguientes parágrafos del BGB, efectuándose la distinción entre incumplimiento total (parágrafo 340) y el cumplimiento inadecuado (parágrafo 341). Además, el parágrafo 339 toma como punto de partida las penas consistentes en la satisfacción de una cantidad de dinero señalando en qué momento son eficaces. Aunque este parágrafo 339 es aplicable también a las penas que consistan en una prestación distinta del dinero, pues así lo preceptúa el parágrafo 342 BGB.

El BGB dedica el primer parágrafo de los que versan acerca de la cláusula penal, a la que denomina pena contractual (Vertragsstrafe), a señalar el momento en que entra en vigor la pena. Ese instante parece que es el de la mora del deudor, conforme al tenor literal del parágrafo 339.1 BGB, aunque veremos que la doctrina alemana añade los casos de imposibilidad de los que sea responsable el deudor. En ambos casos se toma mayoritariamente como punto de partida la noción de culpa del deudor.

Respecto a nuestro Código Civil, es preciso advertir que en los arts. 1.152 a 1.155 no encontramos una disposición tan clara que apunte directamente al incumplimiento total o al cumplimiento inadecuado. Únicamente el art. 1.152.2 CC dispone: «Sólo podrá hacerse efectiva la pena cuando ésta fuere exigible conforme a las disposiciones del presente Código» ${ }^{7}$. Parece mucho más precisa la redacción del parágrafo 339 BGB. Por eso nuestro art. 1.152.2 ha necesitado el esfuerzo de la doctrina con el fin de aclarar esa frase menos concreta ${ }^{8}$.

$\mathrm{Al}$ respecto sostiene Albaladejo': «Puede ser exigida desde el momento en el que se incurra en mora en el cumplimiento defectuoso que sanciona.

7 L. Díez-Picazo y A. Gullón, Sistema de Derecho civil, vol. II, Madrid, 1984, pp. 261-262, señalan los requisitos para la «constitución en mora del deudor», enumerando, entre otros: «exigibilidad de la obligación [...] El acreedor no puede intimar a un deudor al cumplimiento si éste no es debido, y lo será cuando la deuda esté vencida y sea exigible (llegada del término, cumplimiento de la condición, etc.)».

${ }^{8}$ En este sentido, vid. M. Albaladejo «De las obligaciones con cláusula penal», en M. Albaladejo (dir.), Comentarios al Código Civil y Compilaciones forales, t. XV, vol. 2, Arts. 1.125 a 1.155, Madrid, 1983, p. 470: «La pena, en principio, es exigible sólo por incumplimiento o cumplimiento defectuoso que, según las reglas del Código, sea imputable al deudor, pero, por excepción, también es exigible cuando el deudor, aun sin ser culpable, sea responsable por ley o por pacto».

9 Ibid., p. 473. 
Ahora bien, esto hay que entenderlo según las reglas generales de nuestra ley en la materia. De las que se sigue que en las obligaciones de dar o hacer la pena no puede ser exigida hasta que el deudor incurra en mora, lo que generalmente no se produce automáticamente desde que llega el momento de cumplir y no se cumple, sino cuando, llegado aquél, el acreedor exige el cumplimiento. Claro que puede pactarse que, llegado tal momento y no cumpliéndose, se incurra en la pena automáticamente, sin necesidad de que sea exigido el cumplimiento. En cuanto a las obligaciones de no hacer, la pena es exigible tan pronto se realiza el acto prohibido (arg. art. 1.099)». Curiosamente aquí se abordan, para el Derecho español, los dos aspectos que apunta el parágrafo 339 BGB.

Es decir, en nuestro ordenamiento habría que acudir a otras disposiciones distintas de las que el Código Civil dedica a la cláusula penal para aclarar el contenido del art. 1.152.2 ${ }^{10}$.

La doctrina alemana toma como punto de partida que el parágrafo 339.1 presupone la culpa del deudor al mencionar el Verzug (mora), pero que también cabe el pacto en virtud del cual la pena puede exigirse aun sin culpa del deudor en el incumplimiento ${ }^{11}$. Pero también en España caben pactos de ese tipo siempre que no contravengan el art. 1.255 CC.

10 W. Fikentscher y A. Heinemann, op. cit., p. 86, sostienen que la cláusula penal afecta al contenido del contrato y manifiesta, en el fondo, una relación obligatoria particular, que podría estar regulada en la Parte Especial del Derecho de Obligaciones.

${ }^{11}$ R. Dubischar, «Vorbemerkung vor 339 ff.», en R. Wassermann (ed.), Reihe Alternativkommentare. Kommentar zum Bürgerlichen Gesetzbuch, 6 vols., Luchterhand, 1980, p. 451. P. Schlechtriem, Schuldrecht, Allgemeiner Teil, Tübingen, 2000, p. 221, señala la necesidad de culpa del deudor, aunque indica las discusiones respecto de las obligaciones de no hacer. P. GOTTWALD, op. cit., p. 2184, sostiene al tratar las obligaciones de hacer que el deudor puede liberarse probando que no fue culpable de la demora. La eficacia de la pena convencional se liga aquí a la mora en el sentido del parágrafo 286. El deudor objetivamente no realizó la prestación, no se requiere daño para el acreedor. También admite la responsabilidad del deudor, siguiendo a la doctrina dominante, en las obligaciones de no hacer (p. 2185). V. RiEble, «Vorbemerkung zu 339 ff.», en J. Von StAudingers, Kommentar zum Bürgerlichen Gesetzbuch mit Einführungsgesetz und Nebengesetzen, Libro 2, Recht der Schuldverbältnisse, Berlin, 2004, p. 343, señala que el principio de responsabilidad del deudor no puede ser derogado por la autonomía de la voluntad. Y en la p. 346 reconoce que cabe una atenuación de la responsabilidad a través del contrato. J. ECKERT, Schuldrecht. Allgemeiner Teil, Baden-Baden, 2005, p. 72, señala la culpa del deudor (parágrafos 276 y 278) respecto a la lesión de la obligación, aunque esta exigencia no rige para el parágrafo 339.2. En el 339.1 se deduce del presupuesto del Verzug (demora). C. JANOSCHEK, «328345 BGB», en H. G. BAmBerger y H. Roth (eds.), Kommentar zum Bürgerlichen Gesetzbuch, vol. I, 2. ${ }^{a}$ ed., München, 2007, p. 1628, equipara el Verzug (mora) a la imposibilidad de la que deba responder el deudor y en p. 1629 añade que la eficacia de la pena puede hacerse depender de una diligencia cualificada (qualifizierten Verscbulden) o que la pena sea independiente de la culpa. H. Brox y W.-D. WALKER, op. cit., pp. 102-103, explican lo 
Asimismo la Propuesta de Modernización del Código Civil en materia de Obligaciones y Contratos ${ }^{12}$ indica en su art. 1.148: «El acreedor sólo podrá exigir la indemnización previamente convenida cuando el incumplimiento o el cumplimiento defectuoso o retardado sea imputable al deudor. La aplicación de las penas convencionales requerirá la culpa del deudor». Si comparamos esta nueva redacción con el parágrafo 339 BGB resulta, en primer lugar, que el BGB sólo menciona la pena pactada para

que, a su juicio, significa el Schuldnerverzug: consiste en la ausencia de prestación culpable. Por eso la eficacia de la pena contractual presupone culpa del deudor, salvo pacto en contrario. Para las obligaciones de no hacer citan (p. 103) la opinión de la doctrina dominante que presupone culpa del deudor. Cabe que la pena se pacte con independencia de la culpa. H. G. Hermann, op. cit., p. 2069, en virtud de la indicación al Verzug (mora) en el parágrafo 339.1, se exige culpa en las obligaciones de hacer, salvo pacto en contrario. Respecto de las obligaciones de no hacer destaca este autor (p. 2070) el giro de la jurisprudencia alrededor del año 1970 exigiendo, correctamente a su juicio, que el deudor sea culpable. Añade que con ello rompió el BGH una línea tradicional que había sido desarrollada en la Edad Media mediante el postulado de una independencia de la culpa de la pena convencional y que se usaba como instrumento en beneficio del acreedor. Según H. G. HermanN, op. cit., p. 2070, en el siglo XIV respondía el deudor, como afirma Bartolus de Saxoferrato, de la cláusula penal incluso en caso de fuerza mayor. Más adelante sostiene este autor (p. 2071) que constituye una constante jurisprudencia que para la renuncia a la culpa en la cláusula penal deben existir motivos de peso. S. SCHAUB, op. cit., p. 1560, afirma que el parágrafo 339 se extiende también sobre la imposibilidad de la que deba responder el deudor, que excluye el Verzug (mora). Se requiere culpa del deudor para la eficacia de la pena. Señala que cabe pacto en contrario de las partes, aunque con motivos relevantes. También en obligaciones de no hacer se requiere la culpa, salvo pacto en contrario. C. GRÜNEBERG , «339345 BGB», en O. PaLAndt, Bürgerliches Gesetzbuch, vol. 7, München, 2009, p. 548, sostiene para el parágrafo 339.1 que no habrá pretensión de pena si el deudor demuestra que no debe responder de la lesión de la obligación. Cabe pactar la pena independiente de la culpa. La eficacia de la pena puede, en virtud de pacto, hacerse depender de una culpa cualificada. Respecto del parágrafo 339.2 también indica la vigencia del principio de la responsabilidad del deudor, aunque cabe pacto en contrario. D. Medicus, op. cit., p. 609, sostiene respecto del parágrafo 339.1 que el Verzug (mora) presupone culpa, esto es, responsabilidad, conforme al parágrafo 286.IV. Para el parágrafo 339.2 entiende que la culpa también se requiere en las obligaciones de no hacer. Explica la literalidad del parágrafo 339 indicando que en caso de actuación contraria a una obligación de no hacer no cabe hablar, con rigor, de un Schuldnerverzug, sino de una imposibilidad. Por eso añade que induce a error que el parágrafo 339.1 vincule la eficacia de la pena al Schuldnerverzug, porque bastaría también la imposibilidad, a pesar de que ésta excluye el Verzug. En su opinión, los contratantes pueden renunciar a la culpa o pactar una culpa cualificada. M. TAMM, «336-345 BGB», en K. Tonner, A. Willingmann y M. Tamm (eds.), Vertragsrecht, Kommentar, Luchterhand, 2010, p. 574, señala como circunstancias que provocan la eficacia de la pena (Verwirkungstatbestände) el caso de la mora del deudor (Schuldnerverzug), esto es, un cumplimiento no adecuado al plazo (nicht fristgerechter Erfüllung). También puede probar el deudor que no tuvo culpa en el impedimento a la prestación. Tanto en la mora del deudor como en la imposibilidad de la prestación se requiere para la eficacia de la pena culpa del deudor. Y ello tanto para las obligaciones de hacer como de no hacer.

${ }^{12}$ Ministerio de Justicia, Boletín de Información, enero de 2009. 
el caso de incumplimiento o de cumplimiento no adecuado, mientras que en la Propuesta de Modernización del Código Civil se añade una tercera posibilidad como es la mora. Aunque posiblemente esta alusión a la mora no es imprescindible, pues cabría entender subsumido este concepto en la noción de cumplimiento defectuoso. Por otro lado, el parágrafo 339 BGB señala como momento de eficacia de la pena el del retraso del deudor (Verzug), mientras que la Propuesta de Modernización del Código Civil requiere la imputabilidad al deudor. Cuestión ésta de la imputabilidad al deudor que debería quedar sometida a la autonomía de la voluntad. Además, esta mención en la Propuesta de Modernización del Código Civil de la culpa del deudor no añade novedad alguna a lo que ya tenemos en el Código Civil, en concreto, en el art. 1.105, donde queda exonerado de responsabilidad el deudor respecto de «aquellos sucesos que no hubieran podido preverse, o que, previstos, fueran inevitables». Luego cuando no se den estas concretas circunstancias tendrá que responder el deudor. Pero para esto rigen las reglas generales en materia de obligaciones y contratos y no es imprescindible reiterar esta idea en sede de cláusula penal.

Y quizá resulta preferible la vigente redacción del art. 1.152.2 CC que se centra en la exigibilidad y no incide en particular en la problemática de la culpa.

\section{LA CLÁUSULA PENAL EN CASO DE INCUMPLIMIENTO TOTAL}

\section{Su regulación en el BGB y en el Código Civil español}

Aparte del ya expuesto parágrafo 339 BGB que, en mi opinión, no contiene aspectos esenciales o fundamentales para el tema de la cláusula penal, otros parágrafos del BGB sí ahondan en mayor medida en puntos jurídicamente relevantes y permiten reflexionar acerca de cuestiones que realmente quedan centradas en torno a la cláusula penal.

En este sentido, el parágrafo 340 BGB dispone lo siguiente: «(1) Si el deudor prometió la pena para el caso de que no cumpliese su obligación, puede exigir el acreedor la pena ya eficaz en lugar del cumplimiento. Si el acreedor reclama la pena al deudor, queda excluida la pretensión de cumplimiento. (2) Si al acreedor le corresponde una pretensión de indemnización de daños por incumplimiento, puede exigir la pena ya eficaz como importe mínimo del daño. La reclamación de un daño ulterior no queda excluida». 
En primer lugar, conviene destacar que este parágrafo 340 BGB se centra en el incumplimiento total ${ }^{13}$, mientras que el BGB dedica otro parágrafo y distinta solución para el caso del cumplimiento inadecuado (parágrafo 341) (nicht gehörige Erfüllung). El legislador alemán, tras indicar el momento de la eficacia de la pena en un parágrafo, el 339, que encabeza el conjunto de disposiciones dedicadas a la pena contractual, señala en los preceptos siguientes los efectos o las consecuencias que desencadena la entrada en vigor de la pena. Se detecta así una mayor racionalidad en la exposición sistemática, frente a la contenida en nuestro Código Civil ${ }^{14}$.

Además, el parágrafo 339 BGB menciona expresamente tanto el incumplimiento total como el cumplimiento defectuoso o inadecuado, con lo cual sirve a modo de introducción para los preceptos que le siguen.

Acerca del Código Civil español cabría apuntar que, desde luego, no distingue tan claramente como el BGB entre incumplimiento y cumplimiento inadecuado. Una precisión tan meticulosa no se refleja en nuestro Código Civil, que en el art. $1.152^{15}$ apunta al «caso de falta de cumplimiento» ${ }^{16}$. Otra cuestión es que utilizando la interpretación de este precepto se llegue a conclusiones distintas, esto es, que esa literalidad engloba más casos y diferentes del estrictamente enumerado en él ${ }^{17}$.

13 P. GotTWALD, op. cit., p. 2187, señala que el parágrafo 340 BGB regula la relación entre la pretensión que recae sobre la pena contractual y la pretensión de cumplimiento y eventuales pretensiones de indemnización de daños, para el caso de incumplimiento.

${ }^{14}$ C. JANOSCHEK, op. cit., p. 1630: «Una pena establecida para el incumplimiento no es eficaz en caso de cumplimiento inadecuado». También C. GRÜNEBERG , op. cit., p. 548, y P. GotTWALD, op. cit., p. 2188: «Una pena para el caso de incumplimiento no es aplicable en el supuesto de cumplimiento inadecuado (nicht geböriger Erfüllung), especialmente la mora». A mi juicio, gracias a la distinción efectuada en los parágrafos 340 y 341 BGB es posible en el Derecho alemán diferenciar los supuestos y soluciones diversas en cada caso específico.

${ }_{15}$ Art. 1.152: «En las obligaciones con cláusula penal, la pena sustituirá a la indemnización de daños y al abono de intereses en caso de falta de cumplimiento, si otra cosa no se hubiere pactado. Sólo podrá hacerse efectiva la pena cuando ésta fuere exigible conforme a las disposiciones del presente Código».

16 Study Group on a European Civil Code, Principles, Definitions and Model Rules of European Private Law, Draft Common Frame of Reference (DCFR), Full Edition, vol. I, 2009, III, 3:712, bajo la rúbrica de «Pago estipulado para el incumplimiento» señala en su párrafo $1 .^{\circ}:$ «Si los términos de una obligación establecen que el deudor que no cumpla la obligación debe pagar una suma específica al acreedor por tal incumplimiento, el acreedor se encuentra legitimado respecto de esa suma con independencia del daño efectivo». Luego quizá aquí parece tomarse como punto de partida la idea del incumplimiento total y, en el fondo, la no necesidad de prueba del daño.

17 Vid. M. Albaladejo, «De las obligaciones con cláusula penal», op. cit., p. 467: «Aunque el artículo hable sólo de "en caso de falta de cumplimiento" engloba, aun si se piensa que no literalmente, sí, sin duda, en espíritu al menos, también el cumplimiento defectuoso». 


\section{El papel del acreedor en la elección y la protección del deudor}

El punto de partida respecto del parágrafo 340 BGB es su carácter dispositivo $^{18}$.

Respecto al contenido del parágrafo $340 \mathrm{BGB}$, sus dos párrafos se refieren a la verwirkte Strafe, esto es, a la pena ya exigible que puede hacerse efectiva. El parágrafo 340.1 se centra en la posibilidad que se le brinda al acreedor para que reclame o la pena o el cumplimiento (Strafe statt der Erfüllung). Que ambas posibilidades se excluyen lo dispone también este parágrafo 340.1, aunque centrándose sólo en el caso de que se reclame la pena. Si el acreedor reclama la pena se excluye el cumplimiento ${ }^{19}$.

Frente a ello, nuestro Código Civil en el último inciso del art. 1.153 preceptúa: «Tampoco el acreedor podrá exigir conjuntamente el cumplimiento de la obligación y la satisfacción de la pena, sin que esta facultad le haya sido claramente otorgada». Aquí el enfoque de esta disposición señalando la incompatibilidad de reclamaciones parece coincidir con el del parágrafo 340.1 BGB. Pero conviene recordar que el BGB concede esta solución para el caso de incumplimiento total, como se establece en la rúbrica que preside el parágrafo 340, así como en el contenido de su primer párrafo.

Pero nuestro Código Civil en el art. 1.153 ya no matiza si estamos o no ante un incumplimiento total o si hubo cumplimiento inadecuado ${ }^{20}$. De una interpretación sistemática se deduciría que el precepto inmediato anterior nos puede servir de guía. Y el art. 1.152 CC expresamente se ocupa de la «falta de cumplimiento», pero guarda silencio en torno a otros casos que pudieran subsumirse en su letra.

En consecuencia, y ante esta identidad de supuestos y soluciones, quizá cabría concluir que realmente nuestro Código Civil está regulando el caso particular del incumplimiento total en el art. 1.153. No hay que olvidar

${ }_{18}$ Así lo admite la doctrina alemana, P. GotTwald, op. cit., p. 2190, para el parágrafo 340.2; C. JANOSCHEK, op. cit., p. 1631; S. SCHAUb, op. cit., p. 1562, y C. GRÜNEBERG, op. cit., p. 548 .

${ }_{19}$ P. GotTWALD, op. cit., p. 2188, sostiene que el acreedor tiene la elección entre la pena o el cumplimiento, pero carece de ius variandi, esto es, la elección se ha producido cuando exige la pena.

20 Partidas 5, 11 y $34:$ :Pena establecen los hombres [...] en las promesas que hacen, para que sean más firmes y mejor guardadas. Y esta pena se llama en latín conventionalis, que quiere decir pena que es puesta a placer de ambas partes. Y decimos que aunque la pena sea puesta en la promesa, que no está obligado el que la hace de cumplirla y de hacer lo que prometió: sino lo uno tan solamente [...] si cuando hizo la promesa se obligó diciendo que fuese obligado a todo a cumplir la pena y a cumplir la promesa [...] entonces se puede demandar la pena y la cosa prometida». En mi opinión, este último pacto también es posible en el Derecho vigente. 
los antecedentes romanos de la cláusula penal, también para el Derecho alemán ${ }^{21}$. Y parece que en el Derecho romano ${ }^{22}$ lo que importaba era el incumplimiento total ${ }^{23}$.

Incluso en Derecho romano, la pena prevista para el incumplimiento «implicaba una determinación preventiva de la medida de responsabilidad» ${ }^{24}$ cuya función «es la del refuerzo del vínculo obligatorio constriñendo al deudor al cumplimiento de la obligación principal para evitar el pago de la pena que normalmente sería más gravosa para él» ${ }^{25}$. Quizá esta idea de que la pena resulta más gravosa para el deudor late en las actuales opiniones doctrinales que sostienen la imposibilidad de reclamar cantidades mayores a las establecidas por pacto en la pena, que expongo más adelante.

Más claramente, la Propuesta de Modernización del Código Civil en materia de Obligaciones y Contratos sí distingue varios supuestos y sus respectivas consecuencias en el art. 1.149: «El ejercicio de la acción de cumplimiento en forma específica impide al acreedor reclamar la indemnización convenida de los daños y la pena convencional, salvo que éstas hubiesen sido estipuladas para el caso de retraso o que el cumplimiento en forma específica resulte imposible. Si el acreedor obtiene resolución por incumplimiento, tendrá derecho a las indemnizaciones para el supuesto de aquélla pactadas y a las penas convencionales pactadas para el cumplimiento retrasado». Del primer párrafo se deduce claramente la prohibición de acumulación entre cumplimiento y las reclamaciones de daño y pena. Se exceptúa el caso de la mora y el de imposibilidad de cumplimiento en forma específica.

Está claro que la mora no impide un cumplimiento ulterior. Por eso el primer inciso del art. 1.149 de la Propuesta de Modernización permite acumular la reclamación del cumplimiento y la pena pactada para el caso de mora. Pero este primer inciso del art. 1.149 también permite la acumulación cuando «el cumplimiento en forma específica resulte imposible», y este pasaje plantea enormes dudas. La primera cuestión es cómo se puede pedir aún el cumplimiento si el cumplimiento en forma espe-

${ }^{21}$ P. GotTWALD, op. cit., p. 2165, señala los antecedentes históricos apoyándose en el Derecho romano.

22 P. FuenteSECA, Derecho privado romano, Madrid, 1978, p. 210: «pena si no cumple», «pena para el caso de incumplimiento».

${ }^{23}$ E. Ruiz VADILLO, «Algunas consideraciones sobre la cláusula penal», $R D P$, enero-diciembre de 1975 , p. 377, entiende que «le convendría más el nombre de cláusula o pacto sancionador del incumplimiento».

${ }^{24}$ P. Fuenteseca, op. cit., p. 210.

${ }^{25}$ Ibid. 
cífica es imposible. Si hay imposibilidad total a nadie se le podrá pedir ese cumplimiento en forma específica. Sólo cabría pedir el cumplimiento en forma específica si la imposibilidad fuese parcial. Pero es que, además, habría que matizar si tal imposibilidad se produjo con o sin culpa del deudor. Y, por último, determinar si la parte contratante que incurrió en imposibilidad con o sin culpa debía responder de tal circunstancia o si quedó exonerada en virtud de pacto.

Cuando en este primer inciso del art. 1.149 de la Propuesta de Modernización se está aludiendo a que el «cumplimiento en forma específica resulte imposible» cabría, quizá, pensar que es posible incluir en este supuesto los casos de incumplimiento parcial. Y ello porque este precepto no matiza si la imposibilidad es total o parcial, luego cabrían casos en que se pudiera pedir aún un cumplimiento parcial más el equivalente a la parte incumplida debido a la imposibilidad de cumplir en forma específica.

El último inciso de este art. 1.149 de la Propuesta de Modernización del Código Civil parece reconocer la posibilidad de reclamar, además de una indemnización, la pena establecida para el caso de mora. Esto es, junto a la indemnización por incumplimiento, la pena pactada si hubiese, aparte, existido demora. Parece que se trata del incumplimiento total que se traduce en la correspondiente indemnización y al que se suma la mora. Curiosamente en este último inciso del art. 1.149 de la Propuesta de Modernización no se menciona el diverso instante temporal en que generalmente habrán de producirse tanto la mora como el incumplimiento total. Este último, tal vez, habría de situarse al final. Esto es, primero la mora, siendo aún posible el cumplimiento, y, finalmente, el incumplimiento total. Por ello sería posible sumar a la pena derivada del retraso la indemnización correspondiente al incumplimiento total último. Además, este segundo inciso del art. 1.149 de la Propuesta de Modernización sólo permite acumular indemnizaciones pactadas para el caso de incumplimiento con las penas por el retraso. Y no menciona otra pena distinta a la prevista para el caso de mora. Es decir, parece llamar pena a la establecida para la mora e indemnización a la pactada para el incumplimiento. Sin embargo, el art. 1.148 de la Propuesta de Modernización, anteriormente expuesto, denomina indemnización a la prevista en caso de mora.

Por su parte, el Código de Comercio también parece tomar como punto de partida el incumplimiento total en su art. 56: «En el contrato mercantil en que se fijare pena de indemnización contra el que no lo cumpliere, la parte perjudicada podrá exigir el cumplimiento del contrato por los medios de derecho o la pena prescrita; pero utilizando una de estas 
dos acciones quedará extinguida la otra, a no mediar pacto en contrario». Existe, por tanto, también aquí la prohibición de acumulación, aunque se trata de un precepto dispositivo sometido a la autonomía de la voluntad. La Compilación del Derecho Civil Foral de Navarra señala en la Ley 518: «La obligación de pagar la pena, salvo pacto en contrario, no tiene carácter alternativo, sino subsidiario».

El legislador alemán emplea una terminología muy clara: pena en lugar de cumplimiento, en el parágrafo $340.1^{26}$. Se trata nuevamente de una prohibición de acumulación ${ }^{27}$.

${ }^{26}$ Respecto a la vigencia o no de la contraprestación cuando se ejercita la pretensión de cumplimiento, la cláusula penal puede surgir en contratos sinalagmáticos que conllevan obligaciones recíprocas para las partes. Será preciso determinar si habiendo un deudor de una pena, esto es, alguien que o ha incumplido totalmente o ha llevado a cabo un cumplimiento inadecuado, la otra parte contractual, que no forzosamente debe ser el receptor de la pena, ya que ésta puede recibirla, por ejemplo, un tercero (institución benéfica), si esa otra parte contractual se encuentra o no obligada a realizar la prestación. Algunos autores alemanes conceden relevancia al importe de la pena (S. SCHAUB, op. cit., p. 1562, entiende que aún existiría una pretensión sobre la contraprestación si el importe de la pena es tan elevado que sigue constituyendo un medio de presión suficiente, incluso aunque se obtenga la contraprestación. Parece que, a su juicio, en principio se extingue la contraprestación, salvo que del importe de la pena se deduzca lo contrario. Por su parte, C. GRÜNEBERG , op. cit., p. 549, señala que la extinción de la pretensión de cumplimiento se extiende en contratos bilaterales también sobre la contraprestación. Igualmente D. Medicus, op. cit., p. 611, sostiene que en contratos bilaterales decae con la pretensión de cumplimiento también la pretensión sobre la contraprestación. Y vuelve otra vez a insistir en el extremo relativo al importe de la pena P. GotTWALD, op. cit., p. 2189: «Si el acreedor exige la pena contractual ya eficaz en un contrato bilateral, en caso de duda se extingue con la pretensión de cumplimiento también la pretensión sobre la contraprestación. Pero el importe de la pena puede resultar determinante para que la reclamación de la pena no afecte a la obligación de realizar la contraprestación». Incide asimismo en el importe de la pena C. JANOSCHEK, op. cit., p. 1630: «La exigencia de la pena contractual excluye la pretensión de cumplimiento si está fundamentada la pretensión de pena. Si decae o no la pretensión sobre la contraprestación constituye una tarea de interpretación y puede aducirse el importe de la pena»), de modo que el importe de la pena resultará determinante para que continúe subsistiendo la obligación de realizar la contraprestación. Salvo esta excepción, el punto de partida consiste en mantener la extinción de la contraprestación cuando se extingue la pretensión de cumplimiento. [V. Rieble, op. cit., p. 362, mantiene que si el acreedor elige la pena en lugar del cumplimiento (parágrafo 340.1), la pretensión de pena no ocupa el lugar de la pretensión de cumplimiento en el sinalagma. Con el incumplimiento de la prestación que desencadena la pretensión de pena, y como muy tarde con la eliminación de la pretensión de cumplimiento mediante la elección de la pena, se termina la relación recíproca]. Cabría pensar que en Derecho español la solución quizá se encuentre en el art. 1.124 CC.

${ }_{27}$ P. Schlechtriem, op. cit., p. 221, afirma que se protege al deudor en este parágrafo 340.1. En el mismo sentido, P. GotTWALd, op. cit., p. 2188, señala que se protege al deudor porque el acreedor sólo reclamará pena o cumplimiento (Kumulationsverbot). También C. JANOSCHEK, op. cit., p. 1630, y C. GRÜNEBERG , op. cit., p. 548. 
Frente a ello, en otros parágrafos sí se ocupa expresamente de establecer la compatibilidad, como por ejemplo en el parágrafo 341 cuando dice Strafe neben der Erfüllung (pena junto al cumplimiento). Pero en el parágrafo 341 está regulando otro extremo distinto como es el cumplimiento inadecuado.

A través de esta prohibición de acumulación hemos visto que la doctrina alemana mantiene que se protege al deudor porque el acreedor sólo reclamará o pena o cumplimiento. La posibilidad de elegir la ostenta el acreedor $^{28}$. Por lo que concierne a nuestro Código Civil, aparte del último inciso del art. 1.153, que también dispone la prohibición de acumulación ${ }^{29}$, la primera parte de este mismo precepto continúa otorgando al acreedor su derecho a elegir, negándole esta posibilidad al deudor: «El deudor no podrá eximirse de cumplir la obligación pagando la pena, sino en el caso de que expresamente le hubiese sido reservado este derecho» ${ }^{30}$. Pero este último contenido no existe ni en el parágrafo 340 ni en el 341 BGB. Estos últimos centran la figura en torno a lo que puede o no reclamar el acreedor. También el parágrafo 342, que regula la pena que no consiste en dinero, se ocupa de lo que podrá pedir el acreedor. Sí otorga un papel relevante al deudor el parágrafo 343 , que trata de la rebaja de la pena y requiere la previa petición al deudor (auf Antrag des Schuldners).

Concluyendo, la mayoría de los preceptos que el BGB dedica a la pena contractual perfilan la situación del acreedor y determinan las reclamaciones posibles que le asisten ${ }^{31}$. Sin embargo, al deudor le dedican esca-

${ }^{28}$ D. Medicus, op. cit., p. 611, contempla el tema desde el punto de vista de la importancia de la elección del acreedor en relación con la caducidad de la pretensión sobre la pena y sostiene que caduca la pena mediante esa elección del acreedor.

${ }^{29}$ J. Daza Martínez y L. Rodríguez Ennes, Instituciones de Derecho privado romano, Madrid, 1993, p. 274: «La cláusula penal propia consiste en una estructura negocial resultante de la yuxtaposición de dos estipulaciones, una de las cuales tiene carácter principal y la otra penal, para el supuesto de que la primera obligación no se cumpla; la estipulación penal es, pues, accesoria. Se trata, en definitiva, de una nueva obligación condicionada al incumplimiento de la obligación principal. En consecuencia, no se acumulan ambas obligaciones, pues si el deudor cumple su obligación se frustra la condición de la nueva obligación, y si no cumple, pero paga la pena estipulada, queda defendido mediante una excepción de dolo contra la acción de la obligación anterior».

30 Vid. en el mismo sentido la Propuesta de Modernización del Código Civil, art. 1.146.2: «El deudor no podrá eximirse de cumplir la obligación pagando la prestación convenida sino en el caso de que esta facultad le hubiese sido especialmente concedida».

${ }^{31}$ Los dos párrafos del parágrafo 340 BGB toman como punto de partida la reclamación del acreedor (verlangen). La doctrina alemana se ha pronunciado acerca de la elección del acreedor señalando que se trata de un negocio unilateral (J. ECKERT, op. cit., p. 72; C. JANOSCHEK, op. cit., p. 1630; C. GRÜNeBERG , op. cit., p. 548; D. Medicus, op. cit., p. 611, y P. GotTWALD, op. cit., p. 2189), una declaración recepticia (P. GotTWALD, op. cit., p. 2189, y C. JANOSCHEK, op. cit., p. 1630). Que el acreedor pierde la pretensión sobre la pena no 
sa atención, salvo en el parágrafo dedicado a la rebaja de la pena. Frente a ello, nuestro Código Civil sí se ocupa del deudor en el art. 1.153, primer inciso, y de si puede o no eximirse de cumplir la obligación pagando la pena. Esta regulación de la posición del deudor carece de relevancia algu$\mathrm{na}^{32}$, pues ya se le protege a través del segundo inciso del art. 1.153 cuando se establece para el acreedor la prohibición de acumulación. Y la prueba de que sobra, en sede de cláusula penal, esta alusión al deudor, se encuentra en la opinión de nuestro Tribunal Supremo, que en el caso de que se le conceda al deudor la posibilidad de elegir entre cumplimiento y pena reconoce que el supuesto refleja una obligación facultativa ${ }^{33}$.

No debería considerarse cláusula penal la denominada pena de arrepentimiento $^{34}$, esto es, resulta confuso pretender incluirla en el articulado dedicado a la cláusula penal ${ }^{35}$, en concreto el art. $1.153 \mathrm{CC}^{36}$ en su primer inciso.

ya reclamando el cumplimiento, sino aceptándolo (J. ECKERT, op. cit., p. 72; C. GRÜNEBERG , op. cit., p. 549, y P. GoTTWALD, op. cit., p. 2189). La posibilidad de elección que ostenta el acreedor se considera un caso de concurrencia electiva (elektiver Konkurrenz) (C. JANOSCHEK, op. cit., p. 1630, y S. SCHAUB, op. cit., p. 1563) o que el acreedor no tiene una facultad de sustitución (facultas alternativa) siendo una obligación electiva (Elektivschuld) (P. GotTWALD, op. cit., p. 2189).

${ }^{32}$ Aunque los autores sí se ocupan del papel del deudor, M. D. Sanz Cantalejo, «Comentario a la Sentencia de 12 de diciembre de 1991», en CCJC, núm. 28, enero-marzo de 1992, p. 144: «La diferencia entre cláusula penal strictu sensu ex art. 1.152 y pena o multa de arrepentimiento estriba en que en la primera la prestación de la pena no está in facultate solutionis, el deudor no puede liberarse de la obligación pagando la pena, no puede elegir, ya que el acreedor puede pedir el cumplimiento específico — si es posible — en lugar de la pena. En cambio, el art. 1.153 (primera parte), a sensu contrario, faculta al deudor a eximirse del cumplimiento de la obligación principal pagando la pena...».

${ }_{33}$ M. Albaladejo, «De las obligaciones con cláusula penal», op. cit., p. 474: «Que sea un caso de obligación facultativa no se basa en la simple terminología usada por el Tribunal Supremo, sino en darse en el caso las circunstancias de las obligaciones facultativas, como lo demuestra que, extinguida sin culpa del deudor la obligación principal, no viene obligado a pagar la pena, salvo que por ley o por pacto la pena deba de pagarse aun en caso de que del incumplimiento o del cumplimiento inexacto no sea culpable el deudor».

${ }_{34}$ A. Cabanillas Sánchez, «Sección Sexta. De las obligaciones con cláusula penal», en Comentario del Código Civil, t. II, Madrid, Ministerio de Justicia, 1991, p. 159: «En los supuestos en que no hay cláusula penal, el deudor no tiene un derecho de opción entre el cumplimiento y el resarcimiento, sino que tiene que cumplir, y sólo cuando no resulte posible cabrá pedirle el resarcimiento al que sustituye la cláusula penal».

${ }^{35}$ La doctrina española suele reconocer una obligación facultativa. Vid. L. DíEz-PicAzo y A. Gullón, Sistema..., op. cit., vol. II, 2004, p. 160; C. Díaz-Regañón García-Alcalá, «Sección 6. ${ }^{a}$ De las obligaciones con cláusula penal», en R. BERCovitz (coord.), Comentarios al Código Civil, Navarra, 2009, p. 1366, expone la opinión de la doctrina; A. CABANIllas SÁnchez, op. cit., p. 159; E. Ruiz Vadillo, op. cit., p. 388: «Nuestro Código Civil admite, pues, de manera expresa la obligación facultativa en el artículo 1.153».

${ }^{36}$ La doctrina alemana niega el carácter de pena contractual al Reugeld (dinero de arrepentimiento). P. SChleChtRIEM, op. cit., p. 220, sostiene que se trata de una reserva de desis- 
La doctrina alemana se pronuncia también acerca de si el derecho a elegir pena o cumplimiento se puede o no ceder autónomamente ${ }^{37}$, cuestión ésta que tampoco tratan los arts. 1.152-1.155 CC español en particular y que, quizá, habría que negar en Derecho español, pues no hay que olvidar que nos encontramos ante la problemática de una obligación principal y otra accesoria. Incluso en el propio parágrafo 340 no se establece plazo alguno dentro del cual habría de verificarse la elección ${ }^{38}$. Y que en Derecho español se resolvería acudiendo al art. 1.258 CC.

Se le reconoce al acreedor la posibilidad de elegir, e incluso de cambiar su petición. Gottwald ${ }^{39}$ lo admite reconociendo que puede el acreedor reclamar el cumplimiento ${ }^{40} \mathrm{y}$ pasar a hacer valer la pena contractual, aunque todo ello siempre que el acreedor no haya aceptado el cumplimiento ${ }^{41}$.

Pero si el acreedor elige la pena, según Gottwald ${ }^{42}$, «se extingue la pretensión principal. Si, posteriormente, el cumplimiento de la obligación principal es imposible, ello ya no influirá sobre la cláusula penal. Si lo que se convierte en imposible es la pena consistente en entregar algo distinto del dinero, surge la pretensión de reparación de los parágrafos 280 y 283, en su lugar». Y quizá, cabría afirmar lo mismo para el Derecho español.

timiento del contrato, el legitimado se «compra» el desistimiento (erkauft sich); P. GotTWALD, op. cit., p. 2.174, señala que a través del pago del importe puede separarse del contrato (Lösungsklausel); J. ECKERT, op. cit., p. 72, entiende que frente a la cláusula penal, que depende de la subsistencia del contrato, el desistimiento (Rücktritt) presupone separarse del mismo; H. Brox y W.-D. WALKER, op. cit., p. 101, señalan que no es una pena para el caso de incumplimiento o cumplimiento inadecuado, sino que sirve para comprarse el desistimiento (Rücktritt) del contrato; C. GRÜNEBERG , op. cit., p. 546, indica que la pena debe sujetar al deudor para el cumplimiento, el Reugeld le permite separarse del contrato y no se aplican los parágrafos 339 y siguientes, especialmente el parágrafo 343 BGB. En el mismo sentido, M. TAмm, op. cit., p. 573.

37 P. GotTWALD, op. cit., p. 2189, entiende que no.

${ }_{38} \mathrm{Ibid}$., sostiene que el deudor no le puede poner un plazo al acreedor y que el acreedor deberá pronunciarse, conforme a la buena fe, en un tiempo prudencial.

39 Ibid.

${ }^{40}$ Ibid., entiende que tanto el cumplimiento como sus subrogados eliminan la pretensión de pena ya nacida, considerándolo una caso de Verfallbereinigung.

${ }^{41}$ Que el acreedor puede variar su elección también lo afirman H. BROX y W.-D WALKER, op. cit., pp. 103-104, señalando que es posible un cambio de la pretensión de cumplimiento a la reclamación de la pena.

42 P. GotTWALd, op. cit., p. 2189. 
Cristina Fuenteseca Degeneffe Diversos matices de la regulación de la cláusula penal...

\section{La prestación parcial}

Respecto a si una prestación parcial ha de considerarse o no un incumplimiento con el fin de aplicar el parágrafo 340 BGB, la doctrina alemana no es unánime ${ }^{43}$. Desde luego, la letra del parágrafo 340 parece bastante radical: «Prometió la pena para el caso de que no cumpliese su obligación». Y quizá, considerando el contenido del parágrafo $341^{44}$, centrándose en que el deudor no cumple «de modo adecuado, especialmente, no en el tiempo determinado» (nicht in gehöriger Weise, insbesondere nicht zu der bestimmten Zeit), parece que el cumplimiento parcial quedaría englobado en el parágrafo 341, tal vez estamos ante una inadecuación del cumplimiento regulado en este parágrafo 341. El parágrafo 341 BGB permite reclamar pena y cumplimiento, y eso es lo que ocurre cuando hay un cumplimiento parcial. La imposibilidad para acumular pena y cumplimiento sólo se da en caso de incumplimiento total, ahí no cabe reclamar pena y cumplimiento.

En el Derecho español encontramos un precepto que alude expresamente al cumplimiento parcial como es el art. 1.154 permitiéndose la modificación judicial de la pena.

\section{La reparación del daño en lugar de la prestación}

El parágrafo 340.2 BGB se engloba también bajo la rúbrica del incumplimiento que preside todo el precepto con sus dos párrafos. Queda centrado este segundo párrafo en el supuesto concreto de la indemnización

${ }^{43}$ Así, según S. Schaub, op. cit., p. 1562, la prestación parcial (Teilleistung) se tratará como un incumplimiento; en consecuencia, la pena completa será eficaz, aunque hay que devolver la parte objeto de cumplimiento parcial. Otra opinión es la de P. GOTTWALD, op. cit., p. 2188, que entiende que se estará al interés del acreedor. Si éste no es divisible y él reclama la pena contractual, habrá que devolver las prestaciones parciales ya cumplidas. Si el interés del cumplimiento es divisible, puede haber una elección particular para cada parte. De ahí que resulte llamativa la afirmación de F. J. JiMÉNEZ MuÑOZ, «La moderación judicial de la cláusula penal», RCDI, núm 653, julio-agosto de 1999, p. 1461: «A diferencia de los germánicos, los ordenamientos latinos sí admiten la reducción de la cláusula penal en los casos de cumplimiento parcial de la obligación principal, en proporción al cumplimiento realizado».

44 Parágrafo 341 BGB: «(1) Si el deudor ha prometido la pena para el caso de que no cumpla su obligación de modo adecuado (nicht in gehöriger Weise), especialmente, no en el tiempo determinado, puede el acreedor exigir la pena ya eficaz junto al cumplimiento. (2) Si al acreedor le corresponde una pretensión sobre la indemnización de daños por un cumplimiento inadecuado, se aplicará el parágrafo 340.2. (3) Si el acreedor acepta el cumplimiento, sólo podrá reclamar la pena si se reserva este derecho al aceptar el cumplimiento». 
de daños correspondiente por incumplimiento ${ }^{45}$. Se le permite al acreedor reclamar la pena ya exigible como importe mínimo del daño ${ }^{46}$. Pero también se encuentra facultado para reclamar daños ulteriores. En consecuencia, son tres aspectos fundamentales los que trata esta disposición. Primero, la indemnización de daños que sustituye al cumplimiento ${ }^{47}$. Sin embargo, nuestro Código Civil en el art. 1.152.1 no especifica este detalle, pero puede deducirse de su letra. Segundo, la pena como daño míni$\mathrm{mo}^{48}$. El daño mínimo ni se menciona en los arts. 1.152-1.155 CC español ${ }^{49}$. Tercero, la posibilidad que tiene el acreedor de reclamar otros ${ }^{50}$ daños ${ }^{51}$. Este punto tampoco encuentra alusión expresa en nuestro Código Civil. De ahí la afirmación de Díaz Alabart ${ }^{52}$ refiriéndose al art. 1.152.1 CC: «En ninguna parte de este texto aparece dicho que la pena sustituirá la indemnización por daños y perjuicios, sean éstos los que sean [...]

${ }^{45}$ C. GRÜNEBERG , op. cit., p. 548, indica que la pena contractual se incluye en la reparación de daños al existir identidad de intereses.

46 S. Schaub, op. cit., p. 1563, afirma que la pena, como consecuencia de la prohibición de acumulación, es imputable a la reparación de daños.

${ }^{47}$ D. Medicus, op. cit., p. 611, señala respecto del parágrafo 340.2 que se refiere al caso en el cual al acreedor, en lugar de la pretensión de prestación primaria u originaria, sólo le queda una pretensión de reparación de daños en lugar del cumplimiento. En el mismo sentido, M. TAmm, op. cit., p. 576. Vid. para España, M. Albaladejo, «De las obligaciones con cláusula penal», op. cit., p. 468: «Siendo la pena sustitutiva, [...] no cabe que el acreedor exija conjuntamente el cumplimiento exacto de la obligación o en su defecto la indemnización por daños, y además la pena [...] la segunda parte del 1.153, que se ocupa de establecer la inexigibilidad conjunta de cumplimiento exacto y pena si no se pactó».

${ }^{48}$ P. GotTWALD, op. cit., p. 2190: «Si el acreedor junto a la pretensión de pena contractual ostenta una pretensión sobre reparación del daño, no podrá exigir la cláusula penal y, además, toda la reparación de daños, la cláusula penal constituye una especie de indemnización de daños mínimos que no precisa prueba».

49 El Draft, III, 3:712, al regular una suma para el caso de incumplimiento indica que el «acreedor tiene derecho a esa suma con independencia del daño». Lo que sí se permite en el párrafo 2. ${ }^{\circ}$ (III, 3:712) es una reducción de esa suma. Y en los comentarios que siguen a este precepto (Principles, Definitions and Model Rules..., op. cit., p. 962) se distinguen dos posibilidades: la primera, que los tribunales no atenderán al daño efectivamente sufrido, sino a la suma fijada en el contrato; la segunda, que el contrato especifique sólo la suma mínima que deba satisfacer el deudor. En este caso elige el acreedor si opta por una cantidad mayor o menor.

50 C. GRÜNEBERG , op. cit., p. 549, admite que de la interpretación puede resultar que se excluya una pretensión de daños ulteriores.

${ }_{51}$ En este sentido, H. Brox y W.-D. WALKER, op. cit., p. 103, sostienen que la pena constituye un camino simplificado para reclamar indemnización de daños y que la indemnización de daños por incumplimiento se excluye recíprocamente con el cumplimiento. También R. Dubischar, op. cit., p. 443, entiende que la cláusula penal es una vía más sencilla, barata y rápida que el procedimiento de ejecución forzosa. Asimismo, J. ECKERT, op. cit., p. 72.

52 S. DíAz AlabarT, «La cláusula penal y las arras», en El contrato de compraventa, Cuadernos de Derecho Judicial, Madrid, CGPJ, 1993, p. 290. 
siempre que no haya un pacto expreso en el que se diga que la cláusula penal impide que se pueda reclamar más, será posible reclamar el mayor daño sufrido» ${ }^{53}$. Que cabe reclamar los daños que superen a la pena parece admitirlo Ataz ${ }^{54}$.

No parece que el parágrafo 340.2 BGB establezca un límite máximo para el acreedor ${ }^{55}$. Los daños ulteriores sí tendrá que probarlos el acreedor ${ }^{56}$ e incluso es irrelevante que existan daños ${ }^{57}$. Respecto a la ausencia de daños ${ }^{58}$, algunos autores exigen un interés del acreedor digno de protección ${ }^{59}$.

En consecuencia, con arreglo al parágrafo 340.2, el acreedor que exija la pena está reclamando también un daño mínimo, pero esta disposición no excluye que el acreedor haga valer otros daños ${ }^{60}$.

53 Sin embargo, la Propuesta de Modernización del Código Civil en materia de Obligaciones y Contratos señala en su art. 1.147: «La fijación convencional de la indemnización impide al acreedor exigir una cantidad mayor por el daño excedente, salvo que otro hubiera sido el pacto de las partes».

54 J. Ataz López, «Comentario a la Sentencia de 8 de febrero de 1989», en CCJC, núm. 19, enero-marzo de 1989, p. 201: «La aplicación del art. 1.152 [...] si se interpreta en el sentido de que el acreedor no puede, en general, reclamar una indemnización cuando los daños superen a la pena, supone un perjuicio para el acreedor cuando el incumplimiento sea total y no haya cantidades que retener».

55 S. SCHAUB, op. cit., p. 1563, sostiene que la pena puede pactarse también como importe máximo del daño. Pero eso ya entra dentro de la autonomía de la voluntad que, como ya indiqué anteriormente, puede influir sobre estas disposiciones. J. ECKERT, op. cit., p. 73, añade que «la pretensión de pena debe facilitar la reparación del daño y no limitarla».

56 J. ECKerT, op. cit., p. 73, y H. Brox y W.-D. WALKeR, op. cit., p. 104.

57 P. GotTwald, op. cit., p. 2190, afirma que la pena le corresponde en su totalidad al acreedor, incluso si no hubo daño material. También C. JANOSCHEK, op. cit., p. 1631. S. Schaub, op. cit., p. 1562, entiende que resulta insignificante que el deudor pruebe la ausencia de daño para el acreedor.

58 P. GotTwald, op. cit., p. 2188: «La pena contractual no debe servir forzosamente para la compensación de daños patrimoniales, sino también puede dirigirse al aseguramiento de intereses inmateriales. Por ello no es presupuesto la existencia de un daño para la pretensión sobre la pena contractual». W. FikENTSCHER y A. HeInEMAnn, op. cit., p. 87: «La pena contractual es independiente del nacimiento del daño».

59 P. GOTTWALD, op. cit., p. 2189.

${ }^{60}$ Sin embargo, vid. para España M. Albaladejo, «De las obligaciones con cláusula penal», op. cit., p. 468: «Siendo la pena sustitutiva, cabe sólo pedir su pago, pero no cantidad superior, aunque la indemnización por los daños que causen el incumplimiento o el cumplimiento defectuoso penado dé una cifra mayor que la de la pena». También C. DE AmunÁtegui RodRíguez, La función liquidatoria de la cláusula penal en la jurisprudencia del Tribunal Supremo, Barcelona, 1993, p. 173: «... los daños sean superiores a la pena fijada en el contrato, teniendo en tal caso que conformarse el acreedor, quien no podrá reclamar el daño excedente a no ser que haya un pacto en este sentido o que haya existido dolo por parte del deudor. La cláusula funcionaría en tal caso como si se tratase de una limitación de responsabilidad». Al respecto resulta llamativa la sentencia que comenta L.-F. RAGEL SÁNCHEZ, «Comentario a la Sentencia de 7 de diciembre de 1990», en CCJC, núm. 25, eneromarzo de 1991, p. 114: «No se trata de una acumulación de una indemnización por incum- 
Del mismo modo que en el párrafo primero, el parágrafo 340 BGB, párrafo segundo, permite al acreedor exigir, sitúa su figura en primer plano. Aquí también ostenta la posibilidad de elegir, aunque en esta ocasión optará o bien por la reparación del daño en lugar de la prestación, o la pena ${ }^{61}$.

Sin embargo, nuestro Código Civil cuando vincula la pena a la indemnización de daños no expone tan claramente que el acreedor pueda optar, salvo, claro está, que exista un pacto al respecto. En este sentido, el art. 1.152 CC: «En las obligaciones con cláusula penal, la pena sustituirá a la indemnización de daños y al abono de intereses en caso de falta de cumplimiento, si otra cosa no se hubiere pactado». Quizá debería admitirse también en nuestro ordenamiento jurídico la posibilidad de opción para el acreedor entre la reparación del daño o la pena. Porque, tal vez

plimiento contractual a la pena pactada, sino de acumulación de la pena por responsabilidad contractual y de una indemnización por responsabilidad extracontractual, que trata de evitar el enriquecimiento injusto de la parte que obra con dolo o mala fe [...] La indemnización adicional concedida por el Tribunal Supremo a la vendedora no es una indemnización por incumplimiento de contrato, pues esa cifra fue calculada anticipadamente en la cláusula penal: se trata de una indemnización por los daños producidos fuera del contrato, una vez que la compraventa ya había sido resuelta, al continuar utilizando indebidamente los ex compradores la vivienda objeto de la litis [...] Una cosa es la obligación que tiene todo comprador de pagar el precio [...] y otra muy distinta es la obligación que tiene la persona incumplidora, a quien se (p. 115) notifica fehacientemente una resolución de compraventa fundada en Derecho, de desocupar en el plazo más breve posible la finca objeto del contrato resuelto. Esta última obligación no es específica del contrato de compraventa — como sucede con la obligación de pago del precio-, sino que es una manifestación del genérico deber neminem laedere...». A. CABANILLAS SÁnCHEZ, op. cit., p. 158, sostiene respecto al art. 1.152 «que la pena sustituye a la indemnización de daños y al abono de intereses en caso de falta de cumplimiento. Se sustituye únicamente a la indemnización por los daños procedentes del incumplimiento previsto y penado, de manera que no sustituye a los que ocasione otro tipo de defecto de cumplimiento». Quizá cabría pensar en una redacción genérica de una cláusula respecto de la cual no se supiera exactamente sobre qué incumplimiento recae o en un fallo de previsión o cálculo. E. Ruiz VAdillo, op. cit., p. 384, señala: «Es cosa diferente solventar dudas que pueda presentar una cláusula penal y decidir si una cláusula dada es o no penal. Y si para aquel problema el criterio de interpretación restrictiva puede tener alguna justificación, aunque poca, para el que ahora nos ocupa no puede tener ninguna». Interpretación restrictiva del contenido de la cláusula penal frente a otra cuestión como es la decisión en torno a si hay o no cláusula penal. E. RuIz VADILLO, op. cit., p. 410: «Resumiendo: sólo en los casos en que se haya pactado puede, además de la pena, reclamarse el exceso del daño...». Considerando el contenido del parágrafo 340.2 BGB, resulta especialmente llamativa la opinión de I. MARín GARCíA, «La cláusula penal en la Propuesta de Modernización del Código Civil en materia de Obligaciones y Contratos», Indret, Revista para el análisis del derecho, mayo de 2009, Barcelona, www.INDRET.COM, http://ssrn.com/ abstract $=1414395$, p. 6: «El art. 1.147 de la Propuesta parece reiterativo porque recoge una consecuencia necesaria de la función liquidatoria, propia de cualquier cláusula penal —la imposibilidad del acreedor de reclamar el daño excedente-».

${ }^{61}$ En este sentido se pronuncian, M. TAMm, op. cit., p. 576, y J. ECKERT, op. cit., p. 73. 
así, cuando los daños exceden de la pena se evita la doble reclamación de la pena más el daño que excede de ella. Si el acreedor reclama indemnización de daños sólo habría una única petición. Acerca de este extremo quizá resulta más claro el contenido de la Compilación del Derecho Civil Foral de Navarra cuando establece en la Ley 518, párrafo 2. : «La obligación de pagar la pena, salvo pacto en contrario, no tiene carácter alternativo, sino subsidiario, y el acreedor podrá rechazar la oferta de pago de la pena estipulada y exigir la indemnización que resulte debida por el incumplimiento de la obligación principal».

En los preceptos que nuestro Código Civil dedica a la cláusula penal las alusiones a la figura del acreedor no son tan reiteradas como, por ejemplo, en el parágrafo 340 BGB. En este último caso, esas menciones contribuyen a una mayor claridad en la regulación.

Especialmente interesante resulta la distinta función de la reparación de daños en los parágrafos 340 y 341 BGB. Medicus ${ }^{62}$ destaca la alternativa que establece el parágrafo 340 entre pena contractual y reparación del daño. A su juicio, en el parágrafo 340 se trata de una reparación del daño en lugar de la prestación ${ }^{63}$. El acreedor, al existir identidad de intereses, no podrá exigir el subrogado de la prestación y la pena contractual. Frente a ello, en el parágrafo 341 se trata de una reparación de daños diferente al verdadero interés de la prestación, es decir, de los daños derivados de la mora (Verzögerungsschäden) ${ }^{64} \mathrm{y}$ daños de acompañamiento (Begleitschäden). La reparación de estos daños deja insatisfecho el interés de la prestación y, por ello, el acreedor tiene que poder seguir reclamando la prestación junto a la pena ${ }^{65}$.

${ }^{62}$ D. Medicus, op. cit., p. 611.

${ }_{63}$ I. ARANA DE LA FuENTE, «La pena convencional y su modificación judicial. En especial, la cláusula penal moratoria», en $A D C$, t. LXII, fasc. IV, octubre-diciembre de 2009, p. 1597: «Cuando la pena se limite a fijar una suma equivalente al valor previsible de los daños nos hallaremos ante una cláusula de liquidación anticipada de los daños, pero no ante una genuina pena convencional».

${ }_{64}$ J. Delgado EcheverRía, «Comentario a la Sentencia de 3 de octubre de 1985», en CCJC, núm. 9, septiembre-diciembre de 1985, p. 2958: «Podría decirse que esta pena para caso de mora sustituye, en el sentido del art. 1.152, a la indemnización de daños y al abono de intereses correspondientes a la mora, de modo que no podrá exigirse a la vez esta pena y la indemnización por el retraso».

${ }^{65}$ M. TAmM, op. cit., p. 577, distingue también la distinta función de la reparación del daño siguiendo a D. Medicus. 


\section{LA PENA CONTRACTUAL EN CASO DE CUMPLIMIENTO NO ADECUADO}

Debido a la clara y racional exposición sistemática de la cuestión de la cláusula penal en el BGB, el parágrafo 341 se refiere al cumplimiento inadecuado (Strafversprechen für nicht gebörige Erfüllung) desarrollando el contenido del parágrafo 339 que apuntaba ésta como una de las posibles manifestaciones de la cláusula penal.

Veamos, a continuación, el contenido del parágrafo 341 BGB: «(1) Si el deudor ha prometido la pena para el caso de que no cumpla su obligación de modo adecuado (nicht in geböriger Weise), especialmente, no en el tiempo determinado, puede el acreedor exigir la pena ya eficaz junto al cumplimiento. (2) Si al acreedor le corresponde una pretensión sobre la indemnización de daños por un cumplimiento inadecuado, se aplicará el parágrafo 340.2. (3) Si el acreedor acepta el cumplimiento, sólo podrá reclamar la pena si se reserva este derecho al aceptar el cumplimiento».

En este parágrafo 341 BGB, párrafo primero, se admite la acumulación de la pena junto al cumplimiento, siempre que concurran los presupuestos establecidos en este primer párrafo ${ }^{66}$, esto es, cumplimiento inadecuado o retrasado. La cuestión problemática radicará en averiguar qué quiere decir aquí el legislador cuando menciona el cumplimiento inadecuado. Sí parece incluir en él la mora al utilizar la expresión «insbesondere», que significa en particular o especialmente. Luego estaría enumerando un ejemplo de ese que denomina cumplimiento inadecuado ${ }^{67}$. Y, posiblemente, también se incluiría el cumplimiento parcial. Por ejemplo, el cumplimiento que se lleva a cabo en lugar distinto del pactado y la pena contempla este supuesto.

En consecuencia, habría que distinguir los efectos en cada uno de estos supuestos:

En primer lugar, la pena prevista para el caso de mora: se podrá reclamar la pena más el cumplimiento.

Segundo, en caso de pena prevista para el caso de cumplimiento parcial: habrá cumplimiento, aunque parcial, y podrá reclamarse éste, pero

${ }^{66}$ P. GotTwald, op. cit., p. 2194, sostiene que son dispositivos también otros contenidos de los parágrafos 340 y 341 BGB, junto al 341.3.

67 P. Schlechtriem, op. cit., p. 221, habla de mora o prestación defectuosa (Schlechtleistung). J. ECKERT, op. cit., p. 73, explica el cumplimiento inadecuado como un retraso (Verspätung). H. Brox y W.-D. WALKER, op. cit., p. 104, se refieren a que el deudor realice la prestación tarde o mal (verspätet oder schlecht). En el mismo sentido, M. TAMm, op. cit., p. 576 (verspäteten Leistung und der Schlechtleistung). 
también se pedirá la pena proporcional al incumplimiento (por ejemplo, porque la cosa se entregó en lugar distinto del acordado).

Tercero, si la pena se pactase con cierta vaguedad en su tenor literal, por ejemplo, para el caso de cumplimiento inadecuado, habría que distinguir si nos encontramos ante un caso de mora o de incumplimiento parcial y aplicar las soluciones expuestas anteriormente.

Es decir, parece que nos encontramos ante casos en los que aún se puede cumplir o en los que existe un cumplimiento, aunque sea parcial. Y, quizá, quedarían fuera de este parágrafo 341 BGB los supuestos en que no es posible en absoluto el cumplimiento, esto es, no va a existir ningún cumplimiento. Por eso en el parágrafo 341 cabe la acumulación de cumplimiento y pena. Es decir, la pena en este parágrafo 341 no está prevista para el caso de incumplimiento, sino para otras eventualidades que se plantean los contratantes. Frente a ello, el parágrafo 340 BGB sí contempla la pena para el caso de incumplimiento.

Pero, además, dándose el supuesto del parágrafo 341 BGB, esto es, pena para el caso de cumplimiento inadecuado o moroso, puede, finalmente, aparecer un incumplimiento total al cual no será posible aplicarle esta pena que viene prevista para otra circunstancia o finalidad. Más adelante me ocupo de la posibilidad en que se origina, primero la mora y, en última instancia, la situación concluye en un incumplimiento total. Y aunque ambas circunstancias desemboquen en una cantidad de dinero, incluso en nuestro ordenamiento jurídico es preciso distinguir la cláusula penal acordada para el caso de mora, frente a un incumplimiento total no contemplado por aquélla cláusula penal pero sí por otros preceptos del Código Civil que obligan a indemnizar.

El parágrafo 341.2 BGB regula el caso de la reparación de daños que sustituye a la parte de cumplimiento inadecuado y, para este extremo, declara aplicable lo establecido en el parágrafo 340.2, que señalaba que la pena constituirá un daño mínimo y que es posible hacer valer otros daños ulteriores. Ahora bien, tal vez la remisión del parágrafo 341.2 al 340.2 sólo se produce a estos efectos. Es decir, únicamente para regular el punto relativo al daño mínimo ${ }^{68}$ y el extremo que versa acerca de otros posibles daños que puedan surgir ${ }^{69}$. Los demás aspectos se regirán

68 P. Schlechtriem, op. cit., p. 221, entiende la cláusula penal como daño mínimo que no necesita ser probado (parágrafos 341.2 y 340.2 BGB).

${ }_{69}$ R. Dubischar, op. cit., p. 442, sostiene que el acreedor puede pedir daños por incumplimiento por encima del importe de la cláusula penal. 
por el parágrafo 341, que tiene su presupuesto específico consistente en el cumplimiento inadecuado.

El parágrafo 341.3 BGB contempla la obligación del acreedor de reservarse el derecho a reclamar la cláusula penal cuando acepta el cumplimiento ${ }^{70}$. Aquí pueden derivarse consecuencias no beneficiosas para el acreedor, que ignora su obligación de reservarse el derecho a exigir la pena. Y quizá está pensando este parágrafo en el supuesto de la mora en que el cumplimiento puede ser total aunque retrasado. En tal caso cabe reservarse el derecho a reclamar los daños derivados de la mora. Sin embargo, cuando hubo un cumplimiento inadecuado posiblemente no hay aceptación sin más del cumplimiento, sino una inmediata reclamación de la pena por aquella inadecuación.

Sin embargo, la Compilación del Derecho Civil Foral de Navarra señala en la Ley 518, párrafo $3 .^{\circ}$ : «Cuando el acreedor acepte el cumplimiento de la obligación, aunque éste sea parcial, se entenderá renunciada la estipulación penal, salvo que otra cosa se hubiere pactado». Este contenido no parece coincidir en absoluto con el parágrafo 341.3 BGB porque en éste existe la posibilidad de reservarse el derecho a reclamar la pena en el momento en que acepta el cumplimiento.

En consecuencia, para el caso de cumplimiento no adecuado, el acreedor, conforme al parágrafo 341.1 BGB, puede pedir la pena junto $^{71}$ al cumplimiento ${ }^{72}$. Cuando se produzca la inadecuación del cumplimiento o la mora $^{73}$, el acreedor reclamará la pena que constituye un daño

${ }^{70}$ Muchos autores alemanes mantienen el carácter dispositivo del parágrafo 341.3: C. JanoscheK, op. cit., p. 1632; H. Brox y W.-D. Walker, op. cit., p. 104; S. Schaub, op. cit., p. 1564, y C. GRÜNEBERG, op. cit., p. 549.

${ }^{71}$ H. Brox y W.-D. WALKER, op. cit., p. 104, argumentan que se puede pedir pena junto al cumplimiento porque aquí la pena no ocupa el lugar del cumplimiento, sino que sólo asegura el cumplimiento ordenado (Ordnungsmässigkeit der Erfüllung). Idéntica expresión utiliza S. SCHAUB, op. cit., p. 1563, y señala como ejemplo que la pena en un contrato de obra puede exigirse por cada día de retraso en la finalización junto a la conclusión de la obra.

72 R. Dubischar, op. cit., p. 442.

73 M. Albaladejo, «De las obligaciones con cláusula penal», en op. cit., p. 476: «Sólo cuando le haya sido concedido al acreedor el derecho al cumplimiento, o a daños por incumplimiento o cumplimiento inexacto, y, además, a la pena, puede pedir ésta y aquéllos. En tal caso es que la pena es cumulativa [...] Pero la petición de o cumplimiento o daños no es de su elección, sino que tiene derecho al cumplimiento, y sólo en caso de imposibilidad de éste, a los daños, (salvo, ¡claro!, que el deudor se avenga a abonarle voluntariamente éstos, aunque pudiese cumplir, si es que le pide daños en vez de cumplimiento). Con la excepción siempre de que, a tenor del art. 1.124, si se trata de obligaciones recíprocas, de que el acreedor opte por la resolución, y entonces pida daños por incumplimiento y pago de la pena». 
mínimo en virtud de la remisión del parágrafo 341.2 al 340.2 BGB y, aparte, otros daños que pudieran surgir ${ }^{74}$. Aunque cumplimiento habrá, inadecuado o moroso, pero existente. Por eso puede pedirse cumplimiento más pena.

Aunque también podrían aparecer otros supuestos. En este sentido, cabe pensar en una pena establecida para el caso de mora. Si, efectivamente, se produce el retraso, la pena se convierte en exigible. Pero, además, a esta situación puede añadirse otra que es la de un incumplimiento total y definitivo. Habría que cuestionarse si cabría, por un lado, reclamar la pena porque hubo mora y, por otro, aducir el incumplimiento total con el fin de pedir daños y perjuicios.

Quizá la respuesta para el Derecho español debería ser afirmativa: la pena puede exigirse porque se incurrió en mora, que era el presupuesto desencadenante de sus efectos. Y la indemnización de daños y perjuicios derivados del incumplimiento definitivo se deduce del art. 1.101 CC ${ }^{75}$. Resulta llamativo el contenido de la Compilación del Derecho Civil Foral de Navarra, donde se efectúa un claro reparto entre pena e indemnización (Ley 518.3: «Cuando el acreedor acepte el cumplimiento de la obligación, aunque éste sea parcial, se entenderá renunciada la estipulación penal, salvo que otra cosa se hubiere pactado. Cuando cobre la pena y luego exija la indemnización por incumplimiento, la pena cobrada se deducirá de la indemnización que resulte deberse en virtud del contrato»).

Aunque más adelante incido en el tratamiento de la cuestión en el Derecho español, creo que en caso de pena establecida para el supuesto de incurrir en mora el deudor, puede reclamarse conjuntamente el cumplimiento más la pena derivada de la mora. Por ello, si finalmente ese cum-

74 R. Dubischar, op. cit., p. 442.

75 La doctrina alemana se pronuncia acerca del caso en el cual primero concurre un cumplimiento inadecuado y, después, un incumplimiento total. Se plantea la cuestión de si cabe o no pedir la pena en virtud de la primera circunstancia y, además, la indemnización que sustituye al cumplimiento. R. DubISCHAR, op. cit., p. 452: «Conforme al 341 no se excluye que una pretensión indemnizatoria por incumplimiento que surge en lugar de la pretensión de cumplimiento se haga valer junto a la pena contractual, en la medida en que la pena ya era exigible antes del surgimiento de la pretensión indemnizatoria». En el mismo sentido, P. GotTWALD, op. cit., p. 2191, que señala este extremo como no regulado. Admite la acumulación de la pretensión indemnizatoria sustitutiva de la prestación junto a la pena, C. Grüneberg , op. cit., p. 549, y M. TAmm, op. cit., p. 577. S. Schaub, op. cit., p. 1563, entiende que es posible la acumulación cuando se trate de momentos temporales diferentes. Si primero surge una pretensión de pena por cumplimiento inadecuado y si después se transforma la pretensión de cumplimiento en una indemnización de daños por incumplimiento, en tales casos puede exigirse la pena por cumplimiento inadecuado junto a la reparación de daños por incumplimiento. 
plimiento no se produce y del incumplimiento se deriva una indemnización de daños y perjuicios, sería posible pedir estos daños sustitutivos del cumplimiento más la pena por el retraso ${ }^{76}$.

Conviene llamar la atención sobre el contenido de la Propuesta de Modernización del Código Civil en materia de Obligaciones y Contratos cuando en su art. 1.146, en caso de cumplimiento moroso o defectuoso, no alude a la acumulación, salvo pacto, en el mencionado art. 1.146: «La prestación convenida para el incumplimiento o el cumplimiento retrasado o defectuoso sustituirá a la indemnización de daños sin necesidad de probarlos, salvo que las partes le hubiesen asignado sólo carácter penal». Desde luego la terminología empleada, la expresión «defectuoso», parece aproximarse a la utilizada por otros ordenamientos como el alemán cuando mencionan el cumplimiento no adecuado. Pero la solución contenida en el art. 1.146 de la Propuesta de Modernización del Código Civil reúne diversos presupuestos, distintos entre sí (incumplimiento, cumplimiento retrasado o defectuoso), con el fin de darles la misma solución. Y parece admitir la acumulación sólo si hay pacto. Pero no indica qué ocurre si, además de surgir un retraso, la situación desemboca en un incumplimiento total.

Volviendo al ordenamiento alemán, de la misma manera que el parágrafo 340 BGB beneficiaba al deudor porque el acreedor sólo podía elegir pena o cumplimiento, en el parágrafo 341 BGB se le permite la acumulación al acreedor. En mi opinión, se beneficia a este último, por tanto. Según Gottwald ${ }^{77}$, esa posibilidad que brinda el parágrafo 341, de unir la pena al cumplimiento, facilita al acreedor la consecución de sus pretensiones derivadas de un cumplimiento no adecuado al tiempo pactado.

La diferencia fundamental entre el parágrafo 341 BGB y el Derecho español radica en que el art. $1.153 \mathrm{CC}^{78}$ sólo le permite al acreedor acumular cumplimiento y pena cuando así se pactó efectivamente ${ }^{79}$. Ocu-

${ }^{76} \mathrm{~J}$. ECKERT, op. cit., p. 73, sostiene que la reparación de daños por cumplimiento inadecuado (mora) sólo puede pedirla el acreedor cuando el daño sobrepase la pena, rige una compensación forzosa (Anrechnungszwang).

77 P. GotTwald, op. cit., p. 2191.

78 Art. 1.153 CC: «El deudor no podrá eximirse de cumplir la obligación pagando la pena, sino en el caso de que expresamente le hubiese sido reservado este derecho. Tampoco el acreedor podrá exigir conjuntamente el cumplimiento de la obligación y la satisfacción de la pena, sin que esta facultad le haya sido claramente otorgada».

79 C. M. Díez Soto, «Comentario a la Sentencia de 9 de julio de 1991», en CCJC, núm. 26, abril-agosto de 1991, p. 690: «La cláusula penal aparece ligada al pacto por el cual el incumplimiento de cualquiera de las obligaciones derivadas del contrato podrá dar lugar a que se exija su cumplimiento o la resolución. La pena es compatible con el cumplimiento 
rre, sin embargo, que, como señalé anteriormente, este art. 1.153 debería vincularse sistemáticamente al precepto anterior que centra la problemática en la «falta de cumplimiento» (art. 1.152 CC). Con esta interpretación coincidirían tanto el legislador alemán (parágrafo 340) como el español. Es decir, en caso de falta de cumplimiento, sólo previo pacto podrá el acreedor acumular cumplimiento y pena. Pero si estamos tomando como punto de partida que el art. $1.153 \mathrm{CC}$ está regulando un incumplimiento total, la siguiente cuestión consistirá en buscar una ubicación sistemática al cumplimiento inadecuado o moroso ${ }^{80}$.

El único precepto de los cuatro que nuestro Código Civil dedica a la cláusula penal, que quizá podría incluir la mora ${ }^{81}$, sería el art. 1.154 CC ${ }^{82}$ : «El juez modificará equitativamente la pena cuando la obligación principal hubiera sido en parte o irregularmente cumplida por el deudor» ${ }^{83}$. Aquí se está aludiendo al cumplimiento parcial y, dentro del término «irregularmente», tal vez también a la mora ${ }^{84}$. Pero ambos casos sólo se vinculan con la modificación judicial de la pena. Cabría pensar que, por un lado, se está reconociendo un cumplimiento y, por otro, también se admite la vigencia de la pena. Luego tanto si el cumplimiento es parcial

forzoso o con la resolución del contrato; por tanto, aunque su naturaleza no es cumulativa, sino sustitutiva, debe entenderse que estamos ante uno de los supuestos a los que se refiere la segunda parte del art. 1.153».

${ }^{80}$ C. Díaz-Regañón García-AlCalÁ, op. cit., p. 1367, señala: «El establecimiento de una pena moratoria constituye una excepción a la efectividad de la segunda regla del art. 1.153. En esta hipótesis, debido a la propia naturaleza y configuración jurídica de la pena moratoria, son perfectamente compatibles la exigencia del cumplimiento de la obligación principal y la reclamación de la pena sin necesidad de manifestación más o menos explícita por las partes a favor de esa pretendida facultad».

81 J. Delgado EcheverRía, op. cit., p. 236: «La pena pactada para el caso de mora es uno de los supuestos contemplados tanto en la frase final del art. 1.152 ("si otra cosa no se hubiese pactado") como en la segunda parte del art. 1.153, supuesto en que se ha otorgado al acreedor la facultad de exigir conjuntamente el cumplimiento - por equivalente, si por culpa del deudor se ha hecho imposible en forma específica- y la satisfacción de la pena».

${ }_{82}$ F. J. JimÉNEZ MuÑoz, op. cit., p. 1475: «A diferencia de otros ordenamientos, el nuestro no prevé expresamente la posibilidad de estipular una pena para el caso de que se incurra en mora».

${ }^{83}$ L. Dímz-Picazo y A. Gullón, Sistema de Derecho Civil, op. cit., vol. II, 2004, p. 160, consideran el art. 1.154 norma imperativa. I. ARANA DE LA FuENTE, op. cit., p. 1595, entiende que son «imperativas las reglas contenidas en los arts. 1.154 y 1.155 CC».

${ }^{84} \mathrm{El}$ art. 1.085 del Proyecto de 1851 decía: «El juez puede modificar equitativamente la pena estipulada cuando la obligación principal se hubiere cumplido en parte y no en el todo». Luego no se alude, como en la vigente redacción del art. $1.154 \mathrm{CC}$, al cumplimiento irregular. El art. 1.171 del Anteproyecto de Código Civil decía lo mismo que el vigente 1.154 . 
como si es irregular ${ }^{85}$, aún se podrá reclamar tanto el cumplimiento como la pena ${ }^{86}$.

No creo que esta intervención judicial suponga una especialidad típica y propia de la cláusula penal. Cuando existe un cumplimiento parcial o una irregularidad en el cumplimiento de una obligación puede intervenir el juez sin que esta circunstancia sea una característica peculiar impuesta por el art. 1.154 CC. En este sentido, resulta más novedosa la intervención judicial para rebajar penas excesivas o exorbitantes.

Resulta llamativo cómo nuestro Código Civil al ocuparse en el art. 1.154 de la modificación de la pena vuelve otra vez a especificar cuestiones del cumplimiento, esto es, si lo hubo parcial o irregular. Frente a ello, el BGB en su parágrafo 343 se ocupa de la rebaja de la pena (Herabsetzung der Strafe), pero centrándose en aspectos que giran en torno a esta última: que sea desproporcionadamente elevada, que se produzca a petición del deudor, criterios a considerar en la rebaja... Con el fin de aclarar estos extremos me remito al apartado que dedico a la rebaja de la pena.

En consecuencia, tal vez cabría sostener una nueva coincidencia entre el ordenamiento alemán y el español, en particular, del parágrafo 341 y sus soluciones en relación con el art. 1.154 de nuestro Código Civil. Mientras que el BGB se refiere a cumplimiento inadecuado o moroso, nuestro art. 1.154 alude al cumplimiento parcial o irregular ${ }^{87}$. Los efectos también parecen coincidir ${ }^{88}$. Y la ordenación sistemática del BGB es más clara que

85 J. AtAz LÓPEZ, op. cit., p. 199, centra la cuestión en el incumplimiento parcial: «El art. 1.154 [...] no intenta decir que los jueces puedan modificar la pena cuando ésta sea superior a los perjuicios probados, pues ello sería privar de eficacia a la cláusula penal, sino que, por el contrario, lo que el precepto en cuestión pretende es admitir una rebaja de la pena cuando ésta haya sido pactada para el caso de incumplimiento total del deudor y el deudor haya cumplido parcialmente».

${ }^{86}$ I. ARANA DE la Fuente, op. cit., p. 1599, reconoce dos posibilidades para acumular pena e indemnización. La primera, mediante pacto, en virtud del art. 1.152.1, y la segunda, como facultad otorgada al acreedor, en el art. 1.153. Y añade en la p. 1600: «La facultad de acumular cumplimiento específico y pena debe entenderse referida a supuestos de penas previstas para el cumplimiento defectuoso o retrasado de la prestación principal, respecto del cual la doble exigencia de cumplimiento exacto y pena convencional puede estar justificada». En la p. 1650 señala respecto de la pena de demora que «la voluntad de las partes consiste en establecer una pena destinada a resarcir únicamente los daños que origina el mero retraso», esto es, se refiere al pacto previo en torno a la mora.

${ }^{87} \mathrm{El}$ art. 1.153 equivale al art. 1.081.1 del Proyecto de 1851: «El acreedor puede reclamar a su elección el cumplimiento de la obligación o el de la pena estipulada contra el deudor moroso». Aquí el acreedor decide entre una u otra posibilidad y no parece admitirse la reclamación conjunta de cumplimiento y pena en caso de mora. Parece reconocerse, por tanto, una posición más beneficiosa para el deudor.

${ }^{88}$ I. ARANA DE LA FuENTE, op. cit., p. 1598, señala, sin embargo, que «la pena cumula- 
nuestro Código Civil, que en el art. 1.154, al ocuparse de la modificación judicial de la pena, aún vuelve a tratar del cumplimiento ${ }^{89}$.

Aunque resulta fundamental la interpretación de la voluntad de las partes con el fin de concretar si la pena se quiso para un incumplimiento total o para el caso de mora... si en algún caso, por su redacción genérica, no estuviese claro para qué tipo de incumplimiento se pactó la pena y concurriese mora, quizá cabría pensar que, conforme al art. 1.154 CC, se podría pedir cumplimiento de más pena ${ }^{90}$ al reconocerse en dicho precepto tanto un cumplimiento irregular ${ }^{91}$ como la posibilidad de exigir la pena ${ }^{92}$.

$\mathrm{Y}$ aunque sería deseable que nuestro Código Civil recogiese ordenadamente los diversos supuestos de incumplimiento total o cumplimiento parcial o irregular, lo cual facilitaría considerablemente la tarea del intérprete, al menos implícitamente sí se refiere a todos aquellos casos. No con tanta precisión y claridad como el BGB, pero ocupándose de ellos, finalmente.

tiva constituye la excepción en el sistema del Código Civil: sólo opera cuando exista acuerdo expreso».

${ }^{89}$ I. Marín García, op. cit., p. 5: «La Propuesta posibilita que los contratantes estipulen una pena cumulativa [...] aunque, a diferencia del art. 1.153 CC in fine, no establece en qué consiste: junto con la pena, el acreedor podrá reclamar el cumplimiento de la obligación principal en forma específica o por equivalente pecuniario. En relación con otros ordenamientos europeos (francés, italiano y portugués), la pena cumulativa es una singularidad del Derecho español». Respecto de los ordenamientos francés, italiano y portugués, destaca la admisibilidad de la pena cumulativa en caso de mora. Pero, según afirmo en el presente trabajo, eso también implícitamente se deduce del art. 1.154 CC español.

${ }_{90}$ Respecto a los principios contenidos en la Resolución del Consejo de Europa de 20 de enero de 1978, se permite la acumulación en caso de mora. Si hay cumplimiento parcial de la obligación principal cabrá la reducción judicial.

${ }_{91} \mathrm{Y}$ no creo que la mora pueda equipararse a un cumplimiento parcial. La mora es un retraso, puede haber un cumplimiento total, pero tardío. F. J. JimÉNEZ MuÑoz, op. cit., p. 1477: «Nosotros [...] consideramos que no cabe aquí moderación de la pena, ya que no hay posibilidad de cumplimiento parcial: o transcurre la unidad de tiempo de retraso prevista (y hay un cumplimiento total, ya que la pena se establece precisamente para ese retraso) o no transcurre (y no hay entonces ningún incumplimiento)».

92 Precisamente, al reconocerse que algún cumplimiento hubo se está reconociendo que no hay incumplimiento total y que algo queda por cumplir. Vid. M. Albaladejo, «De las obligaciones con cláusula penal», op. cit., p. 485: «Como el Código contempla el supuesto de pena establecida pensando en incumplimiento total, la modificación habrá de ser en menos (reducción o moderación de la pena), ya que el cumplimiento parcial o irregular no puede ser más que el incumplimiento. Pero la pena no puede ser suprimida totalmente porque para no sufrirla nada habría que haber cumplido totalmente». L.-H. CLAVERÍA GosalbeZ, «Comentario a la Sentencia de 20 de mayo de 1986», CCJC, núm. 11, abril-agosto de 1986, p. 3653: «Tampoco ofrece demasiadas dudas la aplicabilidad [...] del art. 1.154 del mismo cuerpo legal, en cuanto se dio un cumplimiento irregular y no un total incumplimiento». 
A esta coincidencia de soluciones entre el BGB y el Código Civil español puede añadirse también el Código Civil italiano. En este sentido, el art. 1.383 dispone: «El acreedor no puede demandar conjuntamente la prestación principal y la penal, si ésta no ha sido estipulada para el simple retraso». Luego en caso de mora sí cabe la acumulación. Pero nada dice este precepto acerca del cumplimiento parcial. Para ello hay que acudir al art. 1.384 CC italiano, dedicado a la reducción de la pena: «La penal puede ser disminuida equitativamente por el juez si la obligación principal ha sido cumplida en parte». Aquí también se opera con la idea de que hay cumplimiento y pena. Especialmente porque este art. 1.384 CC italiano concluye: «Considerando siempre el interés que el acreedor tenga en el cumplimiento». En consecuencia, la disminución o rebaja en el Código Civil italiano se permite en caso de cumplimiento parcial.

\section{LA PENA QUE NO CONSISTE EN UNA PRESTACIÓN PECUNIARIA}

Otro parágrafo del BGB situado en sede de pena contractual y que carece de equivalente entre los preceptos que nuestro Código Civil dedica a la cláusula penal es el parágrafo 342 relativo a la pena que no consiste en dinero: «Si se establece como pena una prestación distinta que el pago de una suma de dinero, se aplicarán las disposiciones de los parágrafos 339 a 341; la pretensión sobre la reparación de daños queda excluida si el acreedor reclama la pena».

Tres aspectos fundamentales se derivan de esta disposición: primero, que está regulando una pena que no consiste en dinero; segundo, que parece delimitar exactamente los parágrafos del BGB que le son aplicables, y tercero, se ocupa de la reparación de daños, excluyéndola cuando el acreedor reclama la pena.

Respecto a los casos en que la pena no consiste en dinero, no los concreta este parágrafo 342 BGB $^{93}$. Tampoco nuestro legislador en sede de cláusula penal, que ni siquiera menciona esta posibilidad. Es la doctrina tanto alemana como española quien sí se ocupa de enumerar algunos supuestos, como la pena consistente en entregar una $\operatorname{cosa}^{94} \mathrm{o}$ la pena que

${ }^{93}$ H. G. Hermann, op. cit., p. 2054, destaca cómo en la Edad Media se utilizaba la Scheltklausel, consistente en que el acreedor quedaba legitimado para burlarse públicamente del deudor y para desacreditarle. En este caso la pena contractual consistía en un deber de soportar que recaía sobre el deudor (Duldungsverpflichtung) (p. 2055).

${ }_{94}$ R. Dubischar, op. cit., p. 453 (Sachleistungen). I. Arana DE la Fuente, op. cit., 
radica en perder un derecho ${ }^{95}$ : «O las partes acuerdan como pena el no llegar a adquirir un derecho que se tendría, como si se establece que por incurrir en el incumplimiento penado se perderá el derecho a revisar cierto precio a tenor del aumento de costes» ${ }^{96}$.

Es importante el tipo de pena no pecuniaria que acuerden las partes, ya que ello repercutirá inevitablemente en otros aspectos como si son o no subsumibles bajo la noción de cláusula penal, si cabe o no la rebaja, o las eventuales consecuencias sobre la reparación de daños.

La Propuesta de Modernización del Código Civil en materia de Obligaciones y Contratos no indica expresamente que la pena puede consistir en una prestación no pecuniaria. Simplemente, bajo la rúbrica «De las cláusulas penales» opera con la idea de una «prestación convenida para el incumplimiento o el cumplimiento retrasado o defectuoso» (art. 1.146). Frente a ello, la actual redacción del Código Civil en los arts. 1.152-1.155 utiliza reiteradamente el término pena sin especificar más su contenido (art. 1.152: «la pena sustituirá» y también «sólo podrá hacerse efectiva la pena»; art. 1.153: «no podrá eximirse de cumplir la obligación pagando la pena» y también «la satisfacción de la pena»; art. 1.154: «modificará equitativamente la pena»). Posiblemente la redacción del Código Civil refleja una importante carga histórica, mientras que la Propuesta de Modernización, quizá intencionadamente, está ofreciendo un apoyo legal para comprender también las penas que no consisten en una prestación pecuniaria. Aunque la actual redacción del Código Civil expresamente ni permite ni prohíbe tales penas. En este sentido, tampoco hacía falta ese cambio de expresión contenido en la Propuesta de Modernización del Código Civil.

p. 1590: «La ley no prohíbe que la pena consista en la entrega de una cosa determinada, pero la posibilidad de moderación judicial, prevista en el art. 1.154 CC, plantearía problemas en tal supuesto».

95 R. Dubischar, R., op. cit., p. 453 (Verwirkung von Rechten), y P. GOTTWALD, op. cit., p. 2.194 (Verfall-und Verwirkungsklauseln). M. Albaladejo, Derecho civil, II, Derecho de Obligaciones, Madrid, 2002, p. 260: «O bien, las partes en un contrato acuerdan que si una de ellas incumple cierta obligación sufrirá la pena de perder algo que la otra le debe por distinto concepto».

${ }_{96}$ M. Albaladejo, Derecho civil, op. cit., II, p. 260. 
Cristina Fuenteseca Degeneffe Diversos matices de la regulación de la cláusula penal...

\section{La pena consistente en la pérdida de derechos}

Acerca de esta última, la doctrina alemana no es uniforme. Así, para algunos estamos ante una pena contractual ${ }^{97}$, mientras que otros distinguen las Verfall-Verwirkungsklauseln de la cláusula penal ${ }^{98}$. Y lo que apuntan los autores alemanes es precisamente si la pérdida de un derecho puede o no considerarse una obligación accesoria. Aunque acaban admitiendo la aplicabilidad de algunos parágrafos del BGB sobre la cláusula penal.

Si lo que se pierden son todos los derechos del deudor suelen coincidir los autores alemanes en la admisión de un Rücktrittsvorbebalt ${ }^{99}$ (reserva de desistimiento). Si la pérdida se produce respecto de derechos singulares reconocen la aplicabilidad de los parágrafos 339 y siguientes ${ }^{100}$, en particular de los parágrafos 343 (rebaja de la pena) y 339.1 (principio de culpabilidad) ${ }^{101}$. Y quizá también para el Derecho español valdría la idea de inclinarse a favor de la aplicación de los artículos relativos a la cláusula penal a los casos de pérdida de derechos singulares. Más dudoso sería

${ }_{97}$ R. Dubischar, op. cit., p. 499, entiende que en las Verwirkungsklauseln se contiene una renuncia a pretensiones propias que la jurisprudencia ha considerado pena contractual. V. Rieble, op. cit., p. 354: «Cuando un acuerdo tiene carácter penal no lo pierde porque en lugar de la prestación se pacte la pérdida de un derecho. De otro modo se permitiría eludir el derecho de pena contractual mediante la entrega por el deudor de la pena al acreedor de una caución o pago para su conducta ordenada o adecuada y que, en caso de pena, sólo pierda la pretensión de devolución, como ocurre con las arras en el parágrafo 338.1». Y en p. 355: «Que también la pérdida de un derecho es una prestación y, con ello, puede ser pena, no significa aún que siempre estemos ante una pena contractual [...] Si la amenaza de pérdida del derecho ejerce especial presión unilateral sobre el deudor, constituye pena. Si se trata de compensar los intereses de ambas partes en la relación jurídica, queda excluida la pena».

98 P. SChlechtriem, op. cit., p. 220, sostiene que no fundamentan ninguna obligación añadida y accesoria, sino que producen una pérdida del derecho. P. GotTWALD, op. cit., p. 2172, entiende que se distinguen de las penas contractuales en que, en caso de lesión contractual, no prevén un pago añadido, sino la pérdida de derechos. J. ECKERT, op. cit., p. 71, afirma que no hay prestación añadida a la principal, y en caso de incumplimiento o cumplimiento inadecuado produce una pérdida de derechos. W. Fikentscher y A. Heinemann, op. cit., p. 87, señalan que, en caso de vulneración, el deudor pierde un derecho. C. GRÜNEBERG , op. cit., p. 546, dice que el deudor pierde derechos propios en caso de incumplimiento o cumplimiento inadecuado. D. Medicus, op. cit., p. 608, indica que el deudor no debe efectuar una prestación añadida como en la cláusula penal y pierde sus derechos.

99 P. Schlechtriem, op. cit., p. 220, citando el parágrafo 360; P. GotTWALd, op. cit., p. 2173; J. ECKERT, op. cit., p. 71, citando parágrafo 360; C. GRÜNEBERG, op. cit., p. 546, citando el parágrafo 354, y D. Medicus, op. cit., p. 608, citando el parágrafo 354.

100 P. Schlechtriem, op. cit., p. 220; P. GotTwald, op. cit., p. 2173; C. GrüneberG , op. cit., p. 546, y D. MEdicus, op. cit., p. 608.

101 C. GrüneberG , op. cit., p. 546, y D. Medicus, op. cit., p. 608. 
admitir, asimismo, el supuesto de la pérdida de todos los derechos del deudor, porque tal vez aquí se operaría con una especie de resolución del contrato. Y para resolver el contrato basta el incumplimiento en las obligaciones recíprocas empleando el art. 1.124 CC sin necesidad de utilizar la noción de cláusula penal.

$\mathrm{Al}$ abordar la cuestión de la pérdida de derechos también se ha ocupado la doctrina de las ventas a plazos en las que el comprador que no paga pierde las cantidades que ya hubiese satisfecho ${ }^{102}$. Este extremo se califica por Rieble como contrario a las buenas costumbres ${ }^{103}$ o como una regulación de la perturbación contractual (Leistungsstörungsregelung) ${ }^{104}$.

\section{La reparación de daños cuando la pena no consiste en dinero}

Por lo que concierne a la remisión expresa del parágrafo 342 a los parágrafos 339 a 341 y la limitación a la reparación del daño que establece, es preciso resaltar lo siguiente. En primer lugar, que el parágrafo 340.2 en materia de daños señala que la pena constituye el daño mínimo y que es posible reclamar daños ulteriores. Esto para el caso de incumplimiento. Si, por el contrario, hay cumplimiento inadecuado, rige el parágrafo 341, que en su párrafo segundo, para la reparación de daños, se remite al parágrafo 340.2. Luego en ambos casos cabe reclamar posibles daños ulteriores que excedan del daño mínimo reflejado en la pena. Esto es lo que preceptúan tanto el parágrafo 340.2 como el parágrafo 341.2. Pero este contenido choca con la regla específica del parágrafo 342, para el caso particular

${ }_{102}$ M. Albaladejo, «De las obligaciones con cláusula penal», op. cit., p. 452: «Pero la pena también puede consistir en cosa distinta de cumplir una obligación penal. Por ejemplo: $1{ }^{\circ}$ Vendiendo algo a plazos, las partes acuerdan que, dejando de pagarse alguno, el contrato se resuelva perdiendo el comprador, como pena por el impago, los plazos ya abonados o parte de ellos». F. J. JimÉNEZ MuÑoz, op. cit., p. 1477: «No obstante, puede pensarse que una solución única para todos los casos sería, igualmente, injusta. Si el incumplimiento tiene lugar no al final, con la mayor parte del precio ya pagado, sino desde los primeros plazos, la cantidad pagada puede ser incluso inferior a los perjuicios irrogados al vendedor, con lo que de moderarse la pena el deudor que incumple incluso saldría beneficiado...».

${ }_{103}$ V. Rieble, op. cit., p. 356: «La pérdida de plazos es generalmente contraria a las buenas costumbres, porque el comprador es castigado más fuertemente con la pérdida sin indemnización de sus pretensiones de devolución, cuanto más fielmente hubiese pagado en el pasado».

${ }_{104}$ Ibid., p. 356: «Que los plazos se los quede el vendedor debe valorarse, atendiendo al importe de los plazos, no como pena, sino como regulación de una indemnización por la utilización comparable con un arriendo (Mietkauf)». 
de la pena que no consiste en dinero, donde si el acreedor reclama la pena no podrá demandar daños. Prevalece este parágrafo 342 sobre el contenido de los parágrafos 340.2 y 341.2 y no se aplican estos últimos. El motivo que suele aducir la doctrina alemana es que no cabe compensar la reparación del daño con una pena no consistente en dinero ${ }^{105}$. Además, esta exclusión expresa contenida en el parágrafo 342 BGB de la reparación de daños si el acreedor reclama la pena, quizá significa que en los otros casos, y siempre que la pena consista en una prestación pecuniaria (pena para el caso de incumplimiento total y pena para el caso de cumplimiento no adecuado), sí se permite reclamar tanto la pena como los daños. Al faltar en nuestro Código Civil un precepto que expresamente se ocupe de la pena que no consiste en una prestación pecuniaria, tampoco tenemos una regulación concreta de lo que ocurre con la reparación de daños si se reclama la pena, pero, efectivamente, pueden surgir dificultades de valoración.

Resulta llamativo que en los Comentarios al art. III, 3:712, del Draft ${ }^{106}$ se destaca que: «Este artículo no se aplica a la opción de pagar una suma de dinero en lugar de cumplir una obligación no monetaria, porque el artículo versa en torno al incumplimiento y no se refiere a obligaciones alternativas o formas de cumplimiento». Pero es que, a mi juicio, este extremo queda fuera de la cláusula penal.

\section{La rebaja de la pena que no consiste en dinero}

El parágrafo $342 \mathrm{BGB}$, como acabo de señalar, preceptúa, en caso de pena que no consista en dinero, que «la pretensión sobre la reparación de daños queda excluida si el acreedor reclama la pena». Rige aquí, por tanto, una normativa particular derivada de la naturaleza de esa pena no pecuniaria que se aparta de los parágrafos precedentes.

Surgen dudas también al abordar la problemática de si en el Derecho alemán admite o no una rebaja esa pena que consiste en una «prestación distinta que el pago de una suma de dinero».

Curiosamente, el parágrafo 342 no menciona expresamente como aplicables a los parágrafos 343 hasta 345, sólo cita desde el 339 hasta el 341. Resulta fundamental determinar si son o no aplicables a las penas no con-

105 R. Dubischar, op. cit., p. 453; P. Schlechtriem, op. cit., p. 221; P. GOTTWALD, op. cit., p. 2194; S. SCHAub, op. cit., p. 1564; C. GrüneberG, op. cit., p. 549; D. Medicus, op. cit., p. 612, у M. ТАMм, op. cit., p. 577.

106 Principles, Definitions..., op. cit., p. 963. 
sistentes en dinero los parágrafos 343 a 345, en particular el 343, dedicado a la rebaja de la pena. Al guardar silencio el BGB acerca de este extremo, es la doctrina alemana quien sí se ha pronunciado sobre tal cuestión, admitiendo mayoritariamente que cabe aplicar los parágrafos 343 hasta 345 también a la pena que no consiste en dinero ${ }^{107}$.

A la hora de rebajar la pena que no consista en dinero pueden surgir dificultades de valoración, y tal vez por este motivo, los parágrafos del BGB no incluyen como expresamente aplicable a las penas no pecuniarias el parágrafo 343 sobre la rebaja de la pena. Tal vez de esta manera se ponen de manifiesto las dudas del legislador. Y ello encajaría con lo que establece en el parágrafo 342 señalando que «la pretensión sobre la reparación de daños queda excluida si el acreedor reclama la pena» y la conclusión de la doctrina alemana afirmando que no cabe compensar la reparación del daño con una pena no pecuniaria, como señalo en el apartado anterior. Por ello, quizá cabría concluir respecto de la rebaja de la pena no pecuniaria que la omisión en el parágrafo 342 de toda alusión a la posibilidad de reducción parece coincidir con el último inciso de este parágrafo 342 BGB. En ambos casos tal vez se está reflejando la cautela del legislador ante posibles dificultades en la valoración, tanto al rebajar una pena no dineraria como también al demandar daños si el acreedor reclama la pena que no consiste en dinero.

Insisten los autores alemanes en destacar el carácter dispositivo del parágrafo $342^{108}$.

En mi opinión, para el Derecho español habría que distinguir si la pena no pecuniaria admite o no una modificación. En ocasiones quizá sí cabe una modificación de la pena que no consiste en dinero. En este sentido, el art. 1.154 CC español se refiere a la modificación de la pena sin especificar o concretar si nos encontramos ante una pena pecuniaria o que no consiste en dinero. La dificultad radica en calificar o no como penas las diversas prestaciones distintas al pago de una suma de dinero. En este sentido, el caso más claro parece el de la pena consistente en entregar una cosa. Habría que analizar cada supuesto en particular con el fin de concretar si cabe o no una modificación. Sin embargo, cuando se trata de la pér-

${ }^{107}$ C. JANOSCHEK, op. cit., p. 1632. S. SCHAUB, op. cit., p. 1564, reconoce que si la prestación consiste en una cosa específica, tras la rebaja queda para el deudor una parte ideal, surge una comunidad de bienes. También cabe que el acreedor entregue una cantidad en dinero. C. GrÜneberG , op. cit., p. 549; D. Medicus, op. cit., p. 612, y M. TAMm, op. cit., p. 577.

${ }_{108}$ P. GotTWald, op. cit., p. 2195; C. Janoschek, op. cit., p. 1632, y S. Schaub, op. cit., p. 1564. 
dida de un derecho, la primera dificultad consiste en aclarar si su naturaleza jurídica es la de una verdadera cláusula penal. Y si lo es, la siguiente cuestión consistirá en determinar si en cada caso concreto se puede admitir una modificación.

\section{LA REBAJA DE LA PENA}

Respecto a la rebaja de la pena, la cuestión principal que se deriva del análisis de los Códigos Civiles español y alemán consiste en determinar si existen o no unos puntos básicos comunes. En concreto, la problemática de las penas exorbitantes o excesivas.

En este sentido, mientras que el BGB parece contemplar con total claridad esta última posibilidad, en nuestro Código Civil no parece tan sencillo encontrar su vigencia. Ni siquiera sometiendo el art. 1.154 CC a una interpretación amplia podríamos llegar a la conclusión de que tal precepto también incluye la pena excesiva, como intentaré demostrar más adelante.

Aunque esta cuestión de la pena excesiva no está exenta de dificultades. No resulta sencillo comprender que las razones que mueven al deudor, de acuerdo con el acreedor, para fijar o determinar el importe de una pena, poco tiempo después se califiquen o se consideren excesivas o exorbitantes. En este sentido, en el Comentario que sigue al art. III, 3:712, del Draft ${ }^{109}$ se indica que el Tribunal puede reducir la suma incluso si ésta, al tiempo de celebrarse el contrato, pareciese razonable.

Quizá debido a estas dificultades nuestro Código Civil parece contemplar una fase previa de la pena que es preciso adaptar al grado de cumplimiento de la obligación en los casos descritos en el art. 1.154: «Cuando la obligación principal hubiera sido en parte o irregularmente cumplida por el deudor». Ante estas dos eventualidades se permite la modificación de la pena ${ }^{110}$. Acerca de este extremo conviene citar asimismo el art. 1.384 CC italiano, que permite la reducción equitativa de la pena por el juez si la obligación principal se cumplió en parte.

Y más dudosos serán los supuestos en que se pida, efectivamente, esa rebaja pero sólo para impugnar el extremo relativo al carácter excesivo o

109 Principles, Definitions..., op. cit., p. 963.

110 Vid., sin embargo, la Ley 518 de la Compilación del Derecho Civil Foral de Navarra: «La estipulación de pagar una cantidad como pena por el incumplimiento de una prestación lícita obliga al promitente, y la pena convenida no podrá ser reducida por el arbitrio judicial». 
exorbitante, ya que el deudor podía haber advertido esto al pactar la pena. El BGB trata de la pena desproporcionada que ya sea eficaz y exigible. Sin embargo, nuestro Código Civil aún no contempla esa fase de la pena, sino un momento anterior.

El art. 1.154 CC español utiliza una expresión quizá no demasiado afortunada cuando dice «modificará equitativamente la pena cuando la obligación principal hubiera sido en parte o irregularmente cumplida por el deudor». Si hay un cumplimiento parcial será necesario rebajar la pena. Sin embargo, cuando la pena estaba prevista para el caso de mora, dándose ésta, la pena en principio se aplicaría tal y como la acordaron los contratantes.

El parágrafo 343 BGB contempla la rebaja (Herabsetzung) de la pena ${ }^{111}$ : «(1) Si una pena ya eficaz es desproporcionadamente elevada, puede ser rebajada, a petición del deudor, mediante una sentencia. Al enjuiciar la proporcionalidad se considerará todo interés legítimo del acreedor, no sólo el interés patrimonial. Tras la satisfacción de la pena queda excluida la rebaja. (2) Lo mismo rige, salvo en los casos de los parágrafos 339 y 342 , cuando alguien promete una pena para el caso de que él haga o no haga algo» ${ }^{112}$.

La rebaja (BGB) ${ }^{113}$ o modificación (Código Civil español) de la pena aparece en ambos Códigos Civiles al final de la regulación de la cláusula

${ }^{111}$ Según P. GotTwald, op. cit., p. 2195, el parágrafo 343 no se encontraba en el Primer Proyecto del BGB.

112 Acerca de la cuestión de si pueden rebajarse no sólo las penas pecuniarias, sino también las que consistan en una prestación distinta del dinero, parece inclinarse la doctrina alemana en torno a la interpretación amplia de la noción de pena, admitiendo la rebaja de penas no pecuniarias [ibid., p. 2197, admite que las partes prevean otras sanciones en caso de penas no dinerarias. Si no las han previsto, puede el tribunal sustituir, en lugar de rebajar, la pena (Ersetzung statt Herabsetzung). Si se pacta como pena una cosa específica, la reducción consistirá en una cuota ideal o, con acuerdo del deudor, en un pago compensatorio. Si se excluye tal solución se permite la rebaja a cero. C. JANOSCHEK, op. cit., p. 1635, en el caso de penas no pecuniarias sostiene que en lugar de la rebaja puede establecerse otra sanción más leve. En caso de pena consistente en una cosa específica coincide con Gottwald: se rebaja una cuota ideal o se entregará una cantidad compensatoria de acuerdo con el deudor. S. SCHAUb, op. cit., p. 1566, afirma que el parágrafo 343 se aplica a penas no pecuniarias, igual que C. GRÜNEBERG , op. cit., p. 550] o de penas incluidas en un contrato porque lo impuso el legislador (R. Dubischar, op. cit., p. 454; P. GotTwald, op. cit., p. 2197; C. JanosCHEK, op. cit., p. 1633, y C. GRÜNEBERG , op. cit., p. 550).

${ }_{113}$ Coincide la doctrina alemana en considerar que el parágrafo 343 tiene carácter imperativo: P. GOTTWALD, op. cit., p. 2196, y C. JANOSCHEK, op. cit., p. 1633, y señala que cabe una renuncia a la rebaja tras la exigibilidad de la pena. H. BROX y W.-D. WALKER, op. cit., p. 105, consideran que es un caso excepcional en el cual el legislador otorga al juez la facultad de incidir en un contrato y que no cabe la autonomía de la voluntad porque debe resultar protegida la parte negocial inexperta. Interesante resulta la opinión de H. G. HERMANN, op. cit., que comienza afirmando que el parágrafo 343 constituye una limitación a la autonomía privada siendo este tipo de ayuda contractual judicial poco frecuente, pero en p. 2.073 ya utili- 
penal. No es el último precepto dedicado a ella, pero la ubicación sistemática en ambos casos es la correcta. En los preceptos anteriores del BGB se trata de una acumulación posible o no entre pena y cumplimiento, mientras que la rebaja de la pena pertenece ya a un momento ulterior, cuando ya definitivamente hay una pena exigible ${ }^{114}$.

Sin embargo, el art. 1.154 CC español en el precepto dedicado a la modificación de la pena aún se ocupa del cumplimiento matizando si lo ha habido en parte o si es irregular. Este extremo debería haberse resuelto antes con el fin de permitir que este art. 1.154 se ocupara de la rebaja de penas excesivas. Eso es lo que hace precisamente el parágrafo 343 BGB, que directamente profundiza en la materia siendo, en consecuencia, su regulación más amplia y específica del punto concreto contemplado ${ }^{115}$. El Código Civil español parece encontrarse en una fase previa en la que aún hay que ajustar la pena al cumplimiento.

Así, del tenor literal del art. 1.154 CC se desprenden pocos datos. Primero, que será el juez quien modifique la pena. Segundo, se utiliza la expresión modificar la pena, mientras que el parágrafo 343 se refiere a rebajar (herabgesetzt). Parece claro que en caso de cumplimiento parcial procedería una rebaja de la pena. Y aunque la expresión modificar podría incluir asimismo un aumento de la pena, quizá habría que admitir dentro del término modificación la rebaja de la pena. Modificar en el art. 1.154 CC quizá significa adaptar la pena a las circunstancias concretas produci-

za la expresión Moderation y sostiene que la moderación depende de la petición del deudor, lo que puede entenderse como una actitud de reserva (Zurückhaltung) frente al paternalismo. Que no cabe la autonomía de la voluntad lo señalan S. ScHAUB, op. cit., p. 1565, y C. GRÜNEBERG , op. cit., p. 550, entendiendo este último que cabe una renuncia a la rebaja tras la exigibilidad de la pena (Verwirkung). También destaca el carácter imperativo del parágrafo 343, M. TAMM, op. cit., p. 577.

114 Algunos autores admiten que no hay que pedir una cifra exacta para la rebaja, C. GRÜNEBERG , op. cit., p. 550, y M. TAMM, op. cit., p. 578.

115 Aunque la rebaja de la cláusula penal no puede pedirla el comerciante, según el parágrafo 348 HGB (P. GotTwald, op. cit., p. 2196; C. JANOSCHEK, op. cit., p. 1633; S. SCHAUB, op. cit., p. 1566; C. GRÜNEBERG , op. cit., p. 550; D. Medicus, op. cit., p. 612, y M. TAMm, op. cit., p. 578), y a éste se le permite acudir a otras vías como la alteración de las circunstancias básicas del contrato (P. GoTTWALD, op. cit., p. 2196; C. JANOSCHEK, op. cit., p. 1633; S. SCHAUB, op. cit., p. 1566, y C. GRÜNEBERG , op. cit., p. 550) o el parágrafo 242 BGB (S. Schaub, op. cit., p. 1566, y C. GRÜNEBERG, op. cit., p. 550). En España, según M. AlbaLADEJO, «De las obligaciones con cláusula penal», op. cit., p. 488: «La moderación de la pena es aplicable a las obligaciones mercantiles», citando Sentencia de 26 de octubre de 1934 . Y en p. 489 añade Albaladejo que cabe una revisión del montante de la cláusula penal por alteración de circunstancias extraordinaria e imprevisible. Vid. también A. Cabanillas SÁnCHEZ, op. cit., p. 161: «Revisión del montante de la pena, pero no en virtud del presente artículo, sino por aplicación de la doctrina jurisprudencial de la cláusula rebus sic stantibus». 
das. Tercero, que ello se hará «equitativamente» ${ }^{116}$. Cuarto, parece que en los casos señalados por el art. 1.154 CC «cuando la obligación principal hubiera sido en parte o irregularmente cumplida por el deudor».

Frente a ello, veamos los requisitos enumerados en el parágrafo 343, párrafo primero, BGB. Primero, la pena ha de ser exigible ${ }^{117}$. Segundo, la pena ha de ser desproporcionadamente elevada. Tercero, es precisa la petición de rebaja formulada por el deudor ${ }^{118}$. Cuarto, la decisión versará sobre una rebaja a un importe adecuado ${ }^{119}$. Quinto, se establecen criterios para determinar el importe adecuado ${ }^{120}$. Sexto, tras el pago de la pena queda excluida la rebaja ${ }^{121}$.

${ }_{116}$ M. Albaladejo, «De las obligaciones con cláusula penal», op. cit., p. 485: «[...] remite el Código al juicio discrecional de equidad del juez no los casos en que deba modificarse la pena (que ésos establece el artículo que son los en que hay algo de cumplimiento), sino el criterio para moderarla o disminuirla, ya que, como he dicho [...] la modificación será en menos».

117 En este sentido, R. Dubischar, op. cit., p. 453; P. GotTwald, op. cit., p. 2197, y C. JANOscheK, op. cit., p. 1634, señalan que la rebaja de la pena sólo es posible tras la Verwirkung, antes no se admite. También S. SCHAUb, op. cit., p. 1566, señala que antes de la Verwirkung no cabe la reclamación. Igual que C. GRÜNEBERG, op. cit., p. 550.

118 En el mismo sentido, R. Dubischar, op. cit., p. 453, y P. GotTWALd, op. cit., p. 2198, señala que la rebaja sólo es posible a petición del deudor y no de oficio, pudiendo el deudor renunciar a la rebaja. C. JANOSCHEK, op. cit., p. 1634, señala que la rebaja es a petición del deudor y no de oficio. C. GRÜNEBERG , op. cit., p. 550, dice que es necesaria una petición del deudor, no cabe la rebaja de oficio. D. Medicus, op. cit., p. 613, se pronuncia en este mismo sentido.

119 M. KiTTNER, Schuldrecht, München, 2003, p. 235, señala que el Juzgado debe comprobar que la cláusula penal tenga un importe adecuado y reducir la cláusula penal que sea desproporcionada.

${ }_{120}$ Criterios que son enumerados por algunos autores: P. SCHLECHTRIEM, op. cit., p. 222, indica el interés en el cumplimiento del acreedor, la medida de la culpa del deudor, la fidelidad contractual anterior del deudor (bisherige Rechtstrene). P. GoTTWALD, op. cit., p. 2199, propone la importancia y medida de la lesión contractual, la peligrosidad para el acreedor, la situación económica de las partes, el importe del daño posible y producido, la culpa del deudor, el interés en impedir ulteriores conductas dañosas. V. RIEBLE, op. cit., p. 349, señala que el parágrao 343 quiere establecer la justicia del caso concreto bajo todos los puntos de vista, también habrá que considerar quién, aparte del deudor, ha contribuido a la entrada en vigor de la pena. J. ECKERT, op. cit., p. 73, señala la dimensión y gravedad de la lesión, el interés del acreedor en evitar la conducta, situación económica del deudor, grado de culpa del deudor, origen de la conducta del deudor. C. JANOSCHEK, op. cit., p. 1635, apunta la gravedad y dimensión de la lesión, grado de culpa, circunstancias del caso concreto, especialmente la función de la pena como medio de presión y aseguramiento, interés del acreedor en impedir esa actuación, tipo de lesión, situación económica del deudor. D. MEdicus, op. cit., p. 612, señala la importancia y proporción de la lesión, su peligrosidad para el acreedor, culpa de quien causa la lesión, considerar si el daño se hubiera producido igual sin la lesión de su obligación por el deudor. M. TAMM, op. cit., p. 578, indica, del lado del acreedor, las exigencias para el aseguramiento de su interés en el cumplimiento y la función de la pena como presión; del lado del deudor, tipo y entidad de la lesión, grado de culpa, su situación económica, su capacidad para efectuar la prestación.

${ }^{121}$ En general, la doctrina alemana señala que cabe que el deudor pague, pero puede 
Cristina Fuenteseca Degeneffe Diversos matices de la regulación de la cláusula penal...

Comparando ambos preceptos está claro que la regulación alemana es mucho más extensa y completa ${ }^{122}$ que la contenida en nuestro art. 1.154 CC ${ }^{123}$. La doctrina alemana se ha preguntado si tal rebaja puede someterse al criterio de árbitros, siendo unánime la respuesta afirmativa ${ }^{124}$. En España posiblemente cabría también esta posibilidad de someter esta cuestión al arbitraje.

Y no cabe detectar cierto paralelismo entre el art. 1.154 CC, ni siquiera con una interpretación amplia de este último, y el parágrafo 343.1 BGB en el concreto extremo relativo a la mención de la rebaja de la pena ${ }^{125}$.

De lo expuesto cabría concluir que el art. 1.154, ante la escasez de su contenido, obliga a doctrina y jurisprudencia españolas a efectuar una ardua tarea interpretativa ${ }^{126}$ ocupándose de cuestiones que deberían haber quedado resueltas por el propio legislador ${ }^{127}$. En este sentido, si tal modificación procede o no de oficio ${ }^{128}$, si cabe o no la modificación respec-

reservarse la petición de rebaja. En este sentido, J. ECKERT, op. cit., p. 73; C. JANOSCHEK, op. cit., p. 1634, y C. GRÜNEBERG , op. cit., p. 550, señala que el pago excluye la rebaja, salvo que expresamente se haya reservado la rebaja.

122 Consideran que el parágrafo 343 protege al deudor: P. SCLeChtRIEM, op. cit., p. 222; P. GotTWald, op. cit., pp. 2195 y 2196; J. ECKerT, op. cit., p. 73, y S. SCHAUb, op. cit., p. 1565.

${ }^{123}$ Suele mantener la doctrina alemana que en el contrato de obra las penas deben tener un límite máximo para superar el control judicial (P. SCHLECHTRIEM, op. cit., p. 222, y P. GOTTWALD, op. cit., p. 2197).

124 P. GOTTWALD, op. cit., p. 2198, y C. JANOSCHEK, op. cit., p. 1634, este último lo afirma tanto para la decisión sobre la rebaja como también para la fijación de la pena. M. TAMM, op. cit., p. 578.

125 V. Rieble, op. cit., p. 305, entiende que en el parágrafo 343 se detecta un control en el ejercicio de los derechos.

126 L. Dí́z-Picazo y A. Gullón, Sistema de Derecho civil, op. cit., II, 2004, p. 160, señalan que el art. 1.154 es una norma imperativa. También C. DíAz-Regañón GARCíA-AlCALÁ, op. cit., p. 1367; A. Cabanillas SÁnChez, op. cit., p. 160, y F. J. JimÉnez MuÑoz, op. cit., p. 1474: «El art. 1.154 del Código Civil debe entenderse que tiene carácter imperativo, y la moderación judicial de la pena convencional ha de realizarse de oficio en defecto de alegación en tal sentido por las partes».

127 Pero tampoco el legislador alemán ha matizado si la rebaja se aplica o no al Reugeld (pena de desistimiento) que la doctrina alemana considera que no puede encuadrarse en la pena convencional. Por ello, los autores alemanes suelen excluir al Reugeld de la posibilidad de rebaja (C. JANOSCHEK, op. cit., p. 1633; S. SCHAUB, op. cit., p. 1566, y C. GRÜNEBERG, op. cit., p. 550). Otro aspecto del que se ocupa la doctrina, pero no el legislador alemán, es el de quién debe probar las circunstancias que legitiman la rebaja y de las que se deduce la desproporcionalidad. Que recae la carga de la prueba sobre el deudor lo afirman S. SCHAUB, op. cit., p. 1565 , у M. TAMM, op. cit., p. 578.

${ }^{128}$ Y plantea dudas también para la jurisprudencia. M. AlbaladeJo, «De las obligaciones con cláusula penal», op. cit., p. 482: «Ahora bien, así como respecto a aquel deber, y no simplemente facultad del juez, de modificar la pena, la jurisprudencia es más uniforme en cuanto a que deba hacerlo ex officio, es decir, aun sin que medie petición de parte, hay sentencias contradictorias». Y añade este mismo autor en p. 482: «Cuando la modifi- 
to de penas no pecuniarias ${ }^{129}$... E incluso la expresión «modificará» del art. 1.154 CC no es tan clara como la de reducir (Herabsetzung) empleada por el legislador alemán, parágrafo $343.1 \mathrm{BGB}^{130}$. Pues en general el término modificar no significa exclusivamente rebajar ${ }^{131}$ y esto produce inevitables reflexiones doctrinales ${ }^{132}$.

cación proceda, aunque no haya sido pedida por las partes, debe (debe y no sólo puede, ya que moderarla es deber y no facultad del Tribunal) decretarse de oficio».

129 Se refiere a la mora, I. ARANA DE LA FuENTE, op. cit., p. 1655: «Cuando el incumplimiento sancionado por la pena sea el retraso [...] si el deudor incurre en dicho retraso habrá que entender, a los efectos de la aplicación de la cláusula penal, que hay incumplimiento total, por lo que no cabe su modificación ex art. 1.154 CC. Esta regla es reiterada por la jurisprudencia [...] como eventual excepción se señalan las obligaciones de tracto sucesivo o de posible división que permitieran cumplimientos parciales aceptados por el acreedor, en las que la facultad moderadora de los tribunales podría operar». Creo que, aunque efectivamente no cabría hablar de modificación de la pena en caso de mora, no debería calificarse este último caso como uno de incumplimiento. Siguiendo a M. Albaladejo, Derecho civil, op. cit., II, p. 184, dentro del cumplimiento inexacto es preciso incluir el «cumplimiento exacto de la prestación debida, pero realizado con retardo o morosamente».

130 El Draft opera con la noción de rebaja de pena excesiva (III, 3:712, párrafo $2 .^{\circ}$ ): «Salvo disposición en contrario, la suma así especificada en un contrato u otro acto jurídico puede ser reducida a un importe razonable si fuera extremadamente excesiva en relación con el daño resultante del incumplimiento y de las otras circunstancias».

${ }^{131}$ I. ARANA DE LA FuENTE, op. cit., p. 1640: «La facultad de los tribunales de modificar la cláusula penal ex art. 1.154 CC no incluye el aumento de penas por ser su importe inferior a la cuantía del daño».

132 Por lo que concierne a los criterios a considerar en la moderación, no se citan expresamente en el Código Civil español, donde únicamente se requiere que la «obligación principal hubiera sido en parte o irregularmente cumplida por el deudor» y ha sido la doctrina quien se ha ocupado de ellos. En este sentido, M. Albaladejo, «De las obligaciones con cláusula penal», op. cit., p. 486: «[...] reducir la pena en proporción a lo que se cumplió, o a lo que no se incurrió en el cumplimiento en el defecto penado, dejando, por tanto, subsistente - podría decirse - la cuantía de la misma que correspondería a lo no cumplido o a aquello en lo que el cumplimiento fuese defectuoso [...] Pero, en mi opinión, ni el grado de culpa del incumplidor ni la intensidad del perjuicio ocasionado deben ser tomados en cuenta para la moderación. No debe serlo la intensidad del perjuicio, porque la pena no depende del perjuicio [...] No debe ser tomado en cuenta tampoco el grado de culpa, ya que éste da lugar a responsabilidad mayor o menor (véanse arts. 1.101 ss.) independientemente de que esté pactada una pena». Y en p. 487 añade este mismo autor: «La menor o mayor culpa, si exime o disminuye la responsabilidad, exime o disminuye la pena, por exención o disminución de responsabilidad en el cumplimiento de la obligación principal, no por moderación de la pena». También I. ARANA DE LA FuENTE, op. cit., p. 1586: «modificación de la pena para ajustarla al grado de cumplimiento parcial o irregular de la obligación por el deudor», y añade en p. 1622: «[...] si el acreedor acepta el cumplimiento parcial o irregular y reclama la penal, el Juez podrá moderar su importe». F. J. JiMÉNEZ MuÑOZ, op. cit., p. 1482: «La cuantía de la moderación no depende de la buena o mala fe del deudor ni de la intensidad de los perjuicios que sufra el acreedor, sino que será proporcional a la parte cumplida o la utilidad de la irregularmente cumplida o, mejor dicho, al perjuicio evitado por el cumplimiento parcial en relación con el perjuicio remanente, dejando subsistente la cuantía de la pena correspondiente a lo no cumplido o a aquello 
Creo que la incidencia de la autoridad judicial en un contrato modificando una pena no puede entenderse desvinculada de los antecedentes históricos. Se consideraba la cláusula penal una figura jurídica peligrosa que era preciso limitar en el sentido de fijar unas fronteras máximas con el fin de evitar lucros indebidos ${ }^{133}$. Al respecto puede citarse C. 7,41,1, Constitución de Justiniano de 531 que establece un límite máximo para la reparación del daño: no podrá exceder del doble del valor del objeto del contrato ${ }^{134}$. Véase lo que expongo al respecto en el apartado que dedico a la cláusula penal en caso de incumplimiento total al indicar que en Derecho romano la pena era más gravosa para el deudor que el cumplimiento de la obligación principal.

Comenzando por la situación en Alemania, hasta bien entrado el siglo XIX dominó en la práctica jurídica el dogma de la limitación de la pena convencional por la cuantía del doble del interés ${ }^{135}$. En la segunda mitad del siglo XIX se negó esta limitación, que fue acogida nuevamente a través del derecho de ponderación judicial en el BGB ${ }^{136}$. La moderación (Moderation) como ponderación judicial procede de la canonística y su «inventor» fue Henricus de Segusio, fallecido en 1270, a quien se debe quizá no la idea de moderación, pero sí su explícita atribución al juez ${ }^{137}$. Respecto a la introducción en el BGB del parágrafo 343, procede de la iniciativa de Otto von Gierke y su escepticismo frente al liberalismo excesivo de las penas contractuales ilimitadas ${ }^{138}$.

Efectivamente, el parágrafo 343 BGB se centra en la rebaja (Herabsetzung) de la pena ${ }^{139}$ y opera con la pena «desproporcionadamente elevada». En el mencionado precepto no se especifica si hubo cumplimiento parcial o irregular. Queda la cuestión centrada en torno a la pena excesiva. Si bien es

en que el cumplimiento fuera defectuoso, y sin que hayan de apreciarse otras circunstancias fuera de las señaladas».

133 P. GOTTWALD, op. cit., p. 2199, sostiene que una pena más elevada no puede ser reducida por debajo del importe del daño efectivamente producido. Respecto a un límite mínimo (absolute Untergrenze) entiende (pp. 2199-2200) que no existe y admite la rebaja a cero de la pena. Más adelante destaco cómo este autor en tal supuesto se está refiriendo a la pena de entregar cosa específica.

${ }^{134}$ Ibid., p. 2199, afirma que una pena que no sobrepase el daño efectivamente producido no puede ser rebajada.

135 H. G. Hermann, op. cit., p. 2058.

136 Ibid., p. 2058.

137 Ibid., pp. 2058-2059.

${ }^{138}$ Ibid., p. 2059. la rebaja.

139 P. GotTWALD, op. cit., p. 2196, sostiene que cabe pactar un plazo para reclamar 
cierto que el parágrafo 343 BGB se sitúa a continuación de los que tratan de la pena en caso de cumplimiento inadecuado (parágrafo 341) y de la pena en caso de incumplimiento (parágrafo 340). Posiblemente el parágrafo 343 está operando, en general, respecto de cualquier pena que sea excesiva ${ }^{140}$.

Nuestro art. 1.154 CC no parece contemplar el caso de las penas excesivas $^{141}$ que el juez «modificará equitativamente».

Que el art. 1.154 CC está pensando en una pena prevista para un incumplimiento total, dándose la circunstancia particular de que en el caso concreto hay cumplimiento parcial, se deduce asimismo de las redacciones que precedieron a su texto definitivo. En este sentido, el art. 1.085 del Proyecto de 1851 decía: «El juez puede modificar equitativamente la pena estipulada cuando la obligación principal se hubiere cumplido en parte y no en el todo» ${ }^{142}$.

Cuestión diferente es la de la pena prevista bien para un incumplimiento total o bien para un incumplimiento parcial o irregular que, en sí misma, resulte desproporcionada. No se trata ya de una pena prevista para incum-

${ }^{140}$ Ibid., p. 2197, al ocuparse de la rebaja de la pena consistente en una cosa específica, admite que si no es posible que la rebaja consista en una cuota ideal o en un pago con acuerdo del deudor, cabría una rebaja a cero.

${ }^{141}$ I. ARANA DE LA FuENTE, op. cit., p. 1633: «Al no existir en nuestro ordenamiento un precepto expreso que permita reducir una pena convencional exorbitante». Y añade en p. 1638: «[...] mientras el legislador no la modifique [...] habrá de resolverse atendiendo al criterio de su validez. Así, ante pena convencional desproporcionadamente alta será preciso determinar si es válida o nula [...] usuraria o abusiva [...] que respete o no los límites generales de la autonomía de la voluntad». También expone esta autora las soluciones propuestas por la doctrina: aplicación analógica del art. 1.154, aplicación del art. 1.103 CC o acudir al principio general que prohíbe el abuso del derecho (pp. 1634-1636). Y en p. 1642 sostiene: «[...] la cláusula penal que estipule una pena "abusiva" o "usuraria" carece de eficacia [...]». Por último, concluye en p. 1683: «El art. 1.154 del Código Civil no debe utilizarse como instrumento que permita al juzgador modificar las cláusulas penales que considere desproporcionadas». F. J. JIMÉNEZ MuÑOz, op. cit., p. 1465: «El Código Civil español, pese a ser del ámbito latino, no contiene previsión alguna sobre la posibilidad de moderación de la pena excesiva con base en la equidad, sin que haya precepto equivalente al art. 1.152.II del Code francés [...] En cambio, en la reducción judicial por parcialidad del incumplimiento de la obligación principal el art. 1.154 del Código español sigue el modelo francés». I. Marín García, op. cit., p. 8, tras señalar que la Propuesta de Modernización del Código Civil en materia de Obligaciones y Contratos permite la moderación de la cláusula penal excesiva, afirma: «[...] la moderación de la pena por razones de equidad no encaja en nuestro ordenamiento jurídico, pues choca con la rigidez extrema en la revisión de los contratos por cambio de circunstancias. Por ello, permitir la moderación de la pena por razones de equidad distorsiona el principio pacta sunt servanda (1.258 CC) al debilitarlo única y exclusivamente cuando se trata de una cláusula penal».

${ }_{142}$ L. Díez-Picazo y A. Gullón, Sistema de Derecho Civil, op. cit., II, 2004, p. 159, se apoyan en una sentencia para afirmar: «La cuantía mayor o menor de la pena nada tiene que ver con la Ley de 1908 prohibitiva de la usura, ni tiene nada que ver con la ilicitud de la causa de los contratos (Sentencia de 19 de febrero de 1985)». 
plimiento total habiéndolo parcial, sino que la pena se establece para un incumplimiento total y concurre tal incumplimiento total, pero la pena resulta desproporcionada. O la pena pactada para un cumplimiento parcial, dándose éste, también es excesiva. Surge el problema de si también cabría aplicar en estos casos el art. 1.154 CC. Literalmente, el art. 1.154 CC no parece contemplar este caso ${ }^{143}$. Y ni siquiera con una interpretación amplia, en el espíritu del art. 1.154 CC, late la idea de que los excesos se van a modificar por el juez.

La Propuesta de Modernización del Código Civil en materia de Obligaciones y Contratos ${ }^{144}$ señala el siguiente contenido para el art. 1.150: «El juez modificará equitativamente las penas convencionales manifiestamente excesivas y las indemnizaciones convenidas notoriamente desproporcionadas en relación con el daño efectivamente sufrido». Se distinguen aquí penas e indemnizaciones, quizá siguiendo la estela marcada por el art. 1.146 de la Propuesta de Modernización del Código Civil anteriormente citado.

Curiosamente en esta nueva redacción se están combinando expresiones que ya contenía y todavía refleja el art. 1.154 CC («el juez modificará equitativamente...») con otras nociones como la del carácter excesivo o desproporcionado de la pena. Esta última idea no se reflejaba antes con tanta claridad en el Código Civil, al menos de modo tan expreso.

Respecto a la redacción contenida en la Propuesta de Modernización del Código Civil, también estimo conveniente resaltar que la expresión «modificará» no parece demasiado afortunada. Si la pena es excesiva lo que va a hacer el juez es rebajarla y no otra cosa. Por ello, modificar quizá resulte algo impreciso. Sería preferible operar con la noción de rebaja.

El contenido del art. 1.150, expuesto anteriormente y reflejado en la Propuesta de Modernización del Código Civil en materia de Obligaciones y Contratos, parece aproximar nuestro ordenamiento jurídico al parágrafo 343 BGB. Aunque falta en esa nueva redacción de la Propuesta de Modernización una alusión a la necesidad de la eficacia de la pena, como requiere el parágrafo $343 \mathrm{BGB}$, con el fin de situar en el tiempo el momento exacto en que procede la modificación equitativa a la que se refiere aquel art. 1.150 de la Propuesta de Modernización del Código Civil.

${ }^{143}$ M. Albaladejo, «De las obligaciones con cláusula penal», op. cit., p. 483: «Pues no se trata en el art. 1.154 de moderar o rebajar una cláusula penal que sea alta y por el solo hecho de que sea alta - por mucho que realmente lo sea—».

144 Boletín de Información, Ministerio de Justicia, enero de 2009. 
Cristina Fuenteseca Degeneffe Diversos matices de la regulación de la cláusula penal...

Por otra parte, este precepto de la nueva redacción de la Propuesta de Modernización del Código Civil no parece referirse expresamente a las penas no pecuniarias, aunque utiliza una expresión tan general que bien podrían entenderse incluidas en ella.

\section{LA INEFICACIA DE LA PROMESA DE PENA}

El parágrafo $344 \mathrm{BGB}^{145}$ preceptúa: «Si la ley declara ineficaz una promesa de prestación, también será ineficaz la pena pactada para el caso de incumplimiento de la promesa, incluso aunque las partes hubiesen conocido la ineficacia de la promesa».

Aquí llama la atención un matiz que no se detecta en otros parágrafos que el BGB dedica a la pena convencional y que precisarían de mayor concreción en este punto. Me refiero a la mención específica del incumplimiento (Nichterfüllung des Versprechens). No hay que olvidar la diferente regulación contenida en el parágrafo 340 BGB (promesa de pena para el caso de incumplimiento) y el parágrafo 341 BGB (promesa de pena para cumplimiento inadecuado). El parágrafo 344 literalmente parece fijarse en la primera posibilidad, esto es, la del incumplimiento. Y la cuestión que surge es si este parágrafo 344 sólo se centra en el incumplimiento o si, por el contrario, abarca también el cumplimiento inadecuado.

Es preciso destacar que en otros parágrafos no se matiza esta problemática del incumplimiento o del cumplimiento inadecuado. Así, el parágrafo 343 BGB, regulador de la rebaja de la pena, sólo alude a una pena desproporcionadamente elevada sin especificar si hubo incumplimiento o cumplimiento inadecuado.

Quizá el parágrafo 344 BGB se concentra sobre el incumplimiento porque está refiriéndose a la ineficacia de la obligación principal. Si esta última es ineficaz tampoco serían válidos los cumplimientos inadecuados. Lo relevante es la ineficacia de la prestación principal, de ahí que no sean posibles los cumplimientos inadecuados.

El parágrafo 344 BGB constituye una muestra de la accesoriedad de la pena respecto de la obligación principal ${ }^{146,147}$.

145 Unwirksames Strafversprechen.

146 C. JanoscheK, op. cit., p. 1636; H. G. Hermann, op. cit., p. 2046, y C. GrüneberG, op. cit., p. 550.

${ }^{147}$ En España destacan la idea de accesoriedad de la obligación penal: M. AlbaLADEJO, «De las obligaciones con cláusula penal», op. cit., p. 490; I. ARANA DE LA FuENTE, op. cit., 
Nuestro Código Civil en el art. $1.155^{148}$ no menciona la necesidad de que la cláusula penal se hubiese pactado para el caso de incumplimiento de la obligación principal, como sí hace el parágrafo 344 BGB. Contemplando la cuestión desde el punto de vista de la ineficacia, quizá resulta preferible la omisión de nuestro Código porque, de este modo, se resalta que lo relevante es la ineficacia de la obligación principal. Si la pena se pactó para un incumplimiento o para un cumplimiento parcial o irregular no es tan importante ante la ineficacia de la obligación primaria.

La Propuesta de Modernización del Código Civil en materia de Obligaciones y Contratos no altera, en su sentido principal, el contenido ya vigente en el Código Civil. La nueva redacción del art. 1.151 establecería: «La nulidad de la cláusula de fijación de indemnización o de pena no lleva consigo la de la obligación principal. La nulidad de la obligación principal lleva consigo la de la cláusula».

Por lo que concierne al contenido de nuestro Código Civil, entiendo, por tanto, que es posible encontrar un precepto semejante al parágrafo 344 BGB. Se trata del art. 1.155 CC donde se destaca, como noción principal, la accesoriedad de la cláusula penal respecto de la obligación principal.

La parte que más se aproxima al parágrafo 344 BGB es el último inciso: «La nulidad de la obligación principal lleva consigo la de la cláusula penal». Pero las primeras líneas del art. 1.155 CC sirven para regular las obligaciones accesorias: «La nulidad de la cláusula penal no lleva consigo la de la obligación principal» ${ }^{149}$. Sin embargo, la Compilación del Derecho Civil Foral de Navarra, en la Ley 518, preceptúa: «El deudor no quedará liberado de la obligación penal aunque concurra alguna causa que pudiera liberarle de la obligación principal». Habría que plantearse los concretos supuestos a los que se refiere este pasaje, esto es, si abarca la nulidad o el caso de la imposibilidad por pérdida de la obligación principal ocasionada por caso fortuito o fuerza mayor.

El propio parágrafo 344 BGB prohíbe la cláusula penal también para el caso de que las partes conociesen la ineficacia de la prestación principal.

\footnotetext{
p. 1591; L. Díez-Picazo y A. Gullón, Sistema de Derecho Civil, op. cit., II, 2004, p. 159;

C. Díaz-Regañón García-Alcalá, op. cit., p. 1369; A. Cabanillas Sánchez, op. cit., p. 161, e I. Marín García, op. cit., p. 10.

148 Art. 1.155 CC: «La nulidad de la cláusula penal no lleva consigo la de la obligación principal. La nulidad de la obligación principal lleva consigo la de la cláusula penal».

149 M. Albaladejo, «De las obligaciones con cláusula penal», op. cit., p. 490: «Pero a igual conclusión habría que haber llegado, en virtud de las reglas generales, aun sin que el Código lo hubiese dispuesto específicamente».
} 
Esto, que lo señala literalmente el parágrafo 344 BGB, también es admitido por la doctrina alemana ${ }^{150}$.

Ciertamente que nuestro art. 1.155 no menciona si las partes son o no conocedoras de la ineficacia de la obligación principal, como sí hace el parágrafo $344 \mathrm{BGB}$, pero ello tampoco es absolutamente imprescindible porque si la prestación principal es ineficaz no se convierte en válida porque las partes conozcan la ineficacia. Los contratantes que pactan una obligación ineficaz habrán de atenerse a las consecuencias sin que el conocimiento de la ineficacia de tal pacto tenga poder taumatúrgico.

En el caso de que la pena a la que se refiere el parágrafo 344 BGB ya hubiese sido satisfecha por el deudor, coinciden los autores alemanes en reconocer una posibilidad de reclamación a través de los parágrafos $812^{151}$ y siguientes $B G B{ }^{152}$.

Y puesto que el parágrafo 344 BGB no enumera los casos a los que se aplica y se limita a exigir que la ley declare una promesa de prestación como ineficaz, es la doctrina alemana quien se ha ocupado de enumerar los supuestos concretos. En este sentido, violación de una prohibición legal por la prestación asegurada ${ }^{153}$; atentado contra las buenas costumbres de la prestación asegurada ${ }^{154}$; impugnabilidad (Anfechtbarkeit) de la obligación principal ${ }^{155,156}$ o nulidad ${ }^{157,158}$; imposibilidad originaria (anfängliche

${ }_{150}$ P. GotTWAld, op. cit., p. 2201; C. GRÜNEBERG , op. cit., p. 550; M. TAMm, op. cit., p. 579, y C. JANOSCHEK, op. cit., p. 1636, este último sostiene que la ineficacia de la obligación principal se extiende sobre la cláusula penal aunque los contratantes ignorasen la ineficacia.

${ }^{151}$ En los parágrafos 812-822 se regula el enriquecimiento sin causa (Ungerechtfertigte Bereicherung).

152 P. GotTwald, op. cit., p. 2201; C. Janoschek, op. cit., p. 1636, y S. Schaub, op. cit., p. 1566.

153 P. GotTWALD, op. cit., p. 2202.

154 Ibid.

155 Ibid.

156 M. Albaladejo, «De las obligaciones con cláusula penal», op. cit., p. 493: «Cuando el acto del que nació la obligación principal es impugnable, pero aún no se ha impugnado, la obligación penal subsiste; aunque, naturalmente, amenazada de destrucción si la otra llega a extinguirse por impugnación del acto de que procede».

157 C. JanOSCHEK, op. cit., p. 1636, y D. Medicus, op. cit., p. 614.

158 A. CABAnillas SÁncheZ, op. cit., p. 161: «El término nulidad debe interpretarse en sentido amplio, es decir, comprensivo de toda causa de ineficacia [...] la cláusula penal será inválida: a) Cuando la obligación principal esté viciada de nulidad absoluta o radical por falta de algún requisito esencial (art. 1.261) o por violar algún precepto legal de orden público (art. 1.255). b) Cuando la obligación principal sea anulable. No obstante, mientras no se produzca la anulación de la obligación principal, la cláusula penal subsiste, aunque amenazada de ineficacia si la obligación principal llega a anularse. c) Cuando la obligación principal sea rescindida [...]». Y no es la primera vez que nuestro Código Civil induce a confusión al emplear la expresión nulidad. 
Unmöglichkeit) de la obligación principal ${ }^{159}$; negocio en fraude de ley ${ }^{160}$; obligaciones naturales ${ }^{161}$, matizando algunos la problemática de las deudas derivadas del juego o apuesta que no pueden imponerse mediante una cláusula penal ${ }^{162}$; defecto de forma en la obligación principal ${ }^{163}$.

Tal vez cabría concluir que el parágrafo 344 BGB y el art. 1.155 CC no difieren apenas en su contenido. Desde luego, la idea esencial en ambos preceptos es idéntica y consiste en destacar la accesoriedad de la obligación penal ${ }^{164}$. También coinciden ambos en mantener un concepto amplio de ineficacia. En el parágrafo 344 BGB no se enumeran los casos concretos de ésta, pero tampoco lo hace nuestro art. 1.155 CC. Este último, al utilizar la expresión de nulidad precisa de la correspondiente interpretación, como ocurre en otros numerosos casos en que nuestro Código Civil alude a la nulidad. En muchos de estos supuestos es necesario ir concretando caso por caso ante qué problemática nos encontramos.

\section{LA CARGA DE LA PRUEBA}

El parágrafo 345 BGB contiene un precepto cuyo contenido, quizá, pertenece más al ámbito del Derecho procesal que al del Derecho civil. No se encuentra equivalente al mismo en los artículos que nuestro Código Civil dedica a la cláusula penal. Tampoco en la Propuesta de Modernización del Código Civil en materia de Obligaciones y Contratos.

El parágrafo 345 establece: «Si un deudor discute la vigencia de la pena, porque él habría cumplido su obligación, debe probar el cumplimiento mientras la prestación debida no consista en un no hacer».

En consecuencia, se trata: primero, de probar el cumplimiento de las obligaciones de hacer, y segundo, cómo se prueba la lesión de las obligaciones de no hacer.

159 P. GotTwald, op. cit., p. 2202.

160 C. JanoscheK, op. cit., p. 1636.

161 P. GotTwald, op. cit., p. 2202, y R. Dubischar, op. cit., p. 454.

162 P. GotTwald, op. cit., p. 2202; C. Janoschek, op. cit., p. 1636; S. Schaub, op. cit., p. 1566, y D. Medicus, op. cit., p. 614.

163 P. GotTwald, op. cit., p. 2202; C. JanoscheK, op. cit., p. 1636, aunque puede subsanarse (parágrafo 311b, párrafo primero, primer inciso), y D. MEDICUs, op. cit., p. 614.

164 E. Ruiz VAdillo, op. cit., p. 396: «[...] la cláusula penal correrá total e incondicionalmente la suerte de la obligación principal, salvo que la misma resulte afianzada por un tercero que siendo capaz, y conociendo la causa de la anulabilidad o rescindibilidad, la renuncie válidamente». 
Del mismo modo que el parágrafo 345 BGB, la doctrina alemana distingue entre las obligaciones de hacer y no hacer. En las obligaciones de hacer es el deudor quien deberá probar el cumplimiento de la obligación ${ }^{165}$, calificándolo algunos de principio de vigencia general ${ }^{166}$. En las obligaciones de no hacer será el acreedor quien deberá probar que el deudor realizó una actuación contraria a la debida ${ }^{167}$. Los autores alemanes sostienen la aplicabilidad del parágrafo 345 BGB a los casos de cumplimiento inadecuado, aunque considerando también el contenido del parágrafo 363 BGB $^{168,169}$. En caso de mora también corresponderá la carga de la prueba al deudor ${ }^{170}$. Si el acreedor reclama un daño que exceda del establecido en la cláusula penal, deberá probar su origen e importe ${ }^{171}$. Pero este parágrafo $345 \mathrm{BGB}$, que versa en torno a la carga de la prueba, sostienen los autores alemanes que es dispositivo, con la excepción del parágrafo $309.12^{172}$ en virtud del cual no se permite cargar al cliente con la prueba ${ }^{173}$.

Concluyendo, el contenido del parágrafo 345 BGB aunque, efectivamente, aclara ciertas cuestiones, tampoco es un precepto imprescindible. $\mathrm{Al}$ regular la carga de la prueba, quizá su ubicación debería encontrarse en una regulación procesal. En este sentido, tal vez resulte más correcto el contenido de nuestro Código Civil que omite cualquier referencia a la prueba en los preceptos dedicados a la cláusula penal. Quizá resulta preferible que el Código Civil se ciña a materias estrictamente civiles.

165 P. Schlechtriem, op. cit., p. 221; P. GotTwald, op. cit., p. 2203; C. Janoschek, op. cit., p. 1636; C. GrünEBERG, op. cit., p. 550; D. Medicus, op. cit., p. 614, citando el BGH, NJW, 69, 875, у M. TAMм, op. cit., p. 579.

166 C. GrÜneBerg, op. cit., p. 550, y M. TAMm, op. cit., p. 579.

167 R. Dubischar, op. cit., p. 454; P. Schlechtriem, op. cit., p. 221; P. P. GotTwald, op. cit., p. 2203; C. JanoscheK, op. cit., p. 1636; S. SCHAUb, op. cit., p. 1567; C. GrüneBERG, op. cit., p. 550; D. Medicus, op. cit., p. 614, y M. TAmm, op. cit., p. 579.

168 En los parágrafos 362-371 se regula el cumplimiento, y, en concreto, el parágrafo 363 contempla la carga de la prueba cuando el acreedor ha aceptado como cumplimiento una prestación que se le ofreció como cumplimiento, y el acreedor no quiere que valga esa prestación como cumplimiento porque fuese otra distinta de la debida o porque hubiese sido incompleta.

169 P. GotTwald, op. cit., p. 2203; C. Janoschek, op. cit., p. 1636; S. Schaub, op. cit., p. 1567; C. GRÜneberg, op. cit., p. 550, y M. TAMm, op. cit., p. 579. La carga de la prueba corresponde al acreedor, añade R. Dubischar, op. cit., p. 454.

${ }_{170}$ P. GotTwald, op. cit., p. 2203, y S. Schaub, op. cit., p. 1567.

171 P. GotTwald, op. cit., p. 2203; C. Janoschek, op. cit., p. 1636, y D. Medicus, op. cit., p. 614.

${ }_{172}$ Este parágrafo regula aspectos de las condiciones generales de la contratación.

173 P. GotTwald, op. cit., p. 2203, y S. Schaub, op. cit., p. 1567. 